\title{
Rising Income Inequality: Technology, or Trade and Financial Globalization?
}

\author{
FLORENCE JAUMOTTE, SUBIR LALL, and CHRIS PAPAGEORGIOU*
}

The paper examines the relationship between the rapid pace of trade and financial globalization and the rise in income inequality observed in most countries over the past two decades. Using a newly compiled panel of 51 countries over a 23-year period from 1981 to 2003, the paper reports estimates that support a greater impact of technological progress than globalization on inequality. The limited overall impact of globalization reflects two offsetting tendencies: whereas trade globalization is associated with a reduction in inequality, financial globalization - and foreign direct investment in particular - is associated with an increase in inequality. [JEL F13, G32, O11, O15, O16, O33] IMF Economic Review (2013) 61, 271-309. doi:10.1057/imfer.2013.7; published online 30 April 2013

\footnotetext{
${ }^{*}$ Chris Papageorgiou is a Senior Economist in the IMF. His work is primarily focused on economic growth and international macroeconomics. He is co-editor of the Journal of Macroeconomics, and associate editor at the European Economic Review and the IMF Economic Review. Subir Lall is an Assistant Director at the IMF. He received his Ph.D. in Economics from Brown University. Florence Jaumotte is a Senior Economist in the IMF. Her work focuses primarily on labor markets and international macroeconomics. She received her Ph.D. in Economics from Harvard University. The authors thank two anonymous referees and the editor Pierre-Olivier Gourinchas for very helpful comments. They also benefited from discussions with Philippe Aghion, Robert Barro, Nancy Birdsall, François Bourguignon, Marcos Chamon, Stijn Claessens, Daniel Cohen, Timothy Callen, Charles Collyns, Angus Deaton, Julian Di Giovanni, Simon Johnson, Ayhan Kose, Prachi Mishra, Martin Ravallion, Martin Schindler, Antonio Spilimbergo, Petia Topalova, Daniel Waldenström, Shang-Jin Wei, and seminar participants at the Federal Reserve Board, Getulio Vargas Foundation, Sao Paolo, IMF, Indian Council for Research and on International Economic Relations, Paris School of Economics, New Economic School, Moscow, and Southern Economic Association Meetings, 2008, Washington, DC. Stephanie Denis and Patrick Hettinger provided excellent research assistance. The views expressed in this study are the sole responsibility of the authors and should not be attributed to the International Monetary Fund, its Executive Board, or its management.
} 
$\mathrm{T}$ echnological progress and globalization are widely regarded as two of the main drivers of recent economic growth. One can broadly think of technological progress as the development and spread of new ideas and methods that enhance productivity and efficiency, and globalization as a catalyst of technology that facilitates the diffusion of ideas and methods around the world through, for example, openness to trade and FDI.

Although the majority of technological innovation occurs in a handful of advanced economies (Helpman and Hoffmaister, 1997; World Bank, 2008), developing countries can potentially and disproportionately benefit from imitation of existing technologies. According to a World Bank report, Global Economic Prospects 2008: Technology Diffusion in the Developing World,

... rapid technological progress in developing countries has helped to raise incomes and reduce the share of people living in absolute poverty from 29 percent in 1990 to 18 percent in 2004. The dismantling of trade barriers in many developing countries over the past 20 years has dramatically increased their exposure to foreign technologies. The ratio of high-tech imports to GDP in developing countries has more than doubled since 1994. The easing of restrictions on FDI has also contributed to technology diffusion within developing countries. FDI is a major source of process technology and 'learning by doing' opportunities. FDI can also have significant spillover effects on domestically-owned enterprises. For example, leading call center companies from France and Spain have paved the way for domestically-owned and export-oriented call centers in Morocco and Tunisia.

Although technology and globalization may be cornerstones of the unprecedented growth of the world economy over the last two decades, what is less clear and still fiercely debated is their distributional effects. Rising inequality across most countries over the past two decades poses one of the greatest challenges to economic policymakers in both developed and developing countries. While improvements in technology, liberal marketoriented reforms, and the entry of China and countries from the former Soviet bloc into the global economy have led to an unprecedented level of integration of the world economy - surpassing the pre-World War I peakthe benefits of rising incomes and aggregate GDP growth rates associated with globalization have not been shared equally across all segments of the population. Indeed, income inequality has risen in most countries and regions over the past two decades, including in developed countries which were thought to have reached levels of prosperity where inequality would level off in line with the predictions of the Kuznets hypothesis. Since this period has also been associated with unprecedented trade and more recently financial integration, much of the debate over rising inequality has focused on the role that globalization - especially of trade - has played in explaining inequality patterns.

Understanding the causes of inequality is fundamental to devising policy measures that can allow the rising prosperity of recent decades to be shared 
more broadly than has been evident so far. Reducing inequality remains important not just from the point of view of achieving a more egalitarian distribution of income and addressing the welfare and social concerns that widening disparities in income raise. As has been seen in some countries recently, these social concerns can lead to social unrest and have reverberations far beyond the borders of a country. To the extent that rising inequality may reflect a lack of economic opportunity, it may itself limit the growth potential of economies by not allowing all economic agents to fully exploit the new opportunities created by globalization and limiting the productive capacity of an economy by not matching capital and labor as efficiently as possible. Moreover, to the extent that economies are periodically subject to shocks of various kinds that limit growth in the short term, greater inequality makes a greater proportion of the population vulnerable to poverty. Finally, rising inequality, if not addressed, can also lead to a backlash against economic liberalization and protectionist pressures, limiting the ability of economies to benefit from globalization. ${ }^{1}$

This paper studies the effects of trade, financial globalization, and technology on income inequality in a large panel of 51 countries over a 23-year period from 1981 to 2003. This paper makes a contribution along several dimensions: First, it uses a large panel data set across both developed and developing countries while existing papers largely address within-country experience for the specific country being studied. Second, it tries to identify the separate effects of both key dimensions of globalization, namely greater trade and greater financial openness, whereas the existing literature thus far has focused primarily on trade with limited attention to financial globalization. In addition, the paper looks at the various subcomponents of trade and financial globalization, including for example exports of manufacturing vs. agriculture, and portfolio debt and equity flows vs. foreign direct investment (FDI). It should be expected that different subcomponents of globalization affect inequality differently. Finally, we assemble a new data set on income inequality (using the World Bank Povcal, and the Luxemburg Income Studies databases) that produces greater methodological consistency in survey-based inequality measurements across countries and over time. As a result, inequality facts across a large number of countries can be more accurately and comprehensively documented.

Our main findings are as follows. The available evidence suggests that income inequality has risen in most countries and regions over the past two decades. Nevertheless, at the same time average real incomes of the poorest

\footnotetext{
${ }^{1}$ There exist voluminous theoretical and empirical literatures on the effects of withincountry income inequality. Some of the most influential theoretical contributions include Greenwood and Jovanovic (1990), Galor and Zeira (1993), Alesina and Rodrik (1994), Benabou (1996), Kremer and Chen (2002), Galor and Moav (2004), and Persson and Tabellini (1994). Prominent contributions from the empirical side include Alesina and Perotti (1996), Perotti (1996), Barro (2000), Forbes (2000), Piketty (2003), Piketty and Saez (2003), Roine and Waldenström (2008), and Sylwester (2000).
} 
segments of the population have increased across all regions and income groups. This suggests that inequality has increased in the upper parts of the distribution in most countries, a fact consistent with recent evidence in the United States and the United Kingdom. Our analysis finds that increasing trade and financial globalization have had separately identifiable and opposite effects on income distribution. Trade liberalization and export growth are found to be associated with lower income inequality, while increased financial openness is associated with higher inequality. However, their combined contribution to rising inequality has been much lower than that of technological change, both at a global level and especially markedly in developing countries. The spread of technology is, of course, itself related to increased globalization, but technological progress is nevertheless seen to have a separately identifiable effect on inequality. The disequalizing impact of financial openness - mainly felt through FDIand technological progress both appear to be working by increasing the premium on higher skills and possibly higher returns to capital, rather than limiting opportunities for economic advancement. Consistent with this, increased access to education is associated with more equal income distributions on average.

To gain further insight into the impact of globalization on inequality, we also estimated our model using the income shares of the five quintiles of the population as dependent variables. Interestingly, the effects on the bottom four quintiles are qualitatively similar and in the opposite direction from that on the richest quintile. Export growth is associated with a rise in the income shares of the bottom four quintiles and a decrease in the share of the richest quintile. In contrast, financial globalization and technological progress are shown to benefit mainly the richest 20 percent of the population.

There exists a vast empirical and theoretical trade literature on the effects of globalization on inequality. Although the peak of this vibrant literature was reached in the mid-1990s with a series of major contributions (for example, Feenstra and Hanson, 1996; Borjas, Freeman, and Katz, 1997), there is a renewed interest in the topic (for example, Broda and Romalis, 2008; Krugman, 2008), including a great body of work on developing countries surveyed in Goldberg and Pavcnik (2007), and a recent spike in theoretical research (for example, Verhoogen, 2008; Egger and Kreickemeier, 2009). ${ }^{2}$ There also exists a voluminous literature on the effects of financial globalization on growth and volatility (see Prasad and others, 2007; Kose and others, 2009 for comprehensive reviews). However, there has been surprisingly limited attention to the effects of financial globalization on inequality (exceptions include Roine, Vlachos, and Waldenström, 2008; and the review articles by Claessens and Perotti, 2007; Demirgüç-Kunt and Levine, 2007). Finally, a related literature investigates the effect of skill

\footnotetext{
${ }^{2}$ Also see Ravallion $(2004,2006)$ for related work on trade globalization and poverty.
} 
biased technical change on inequality (for example, Berman, Bound, and Griliches, 1994; Berman, Bound, and Machin, 1998). This paper contributes to the globalization-inequality literature by examining the effects of trade, financial globalization, and technology on income inequality in a comprehensive framework using a large panel of countries.

The rest of the paper is organized as follows. Section I examines the patterns in inequality and globalization across a broad range of developed and developing countries over the past two decades, and describes the unique inequality data set that is used in the empirical estimation. Section II discusses some of the channels through which trade and financial globalization may be expected to influence inequality within countries, whereas Section III analyzes the empirical evidence to identify the main factors explaining inequality. Section IV discusses the implications of the empirical findings with particular emphasis on plausible mechanisms responsible for the rising income inequality. Section V concludes.

\section{A Look at Cross-Country Trends}

This section provides a brief review of the evidence on inequality and globalization over the past two decades and across income groups. ${ }^{3}$

\section{Income Inequality}

Cross-country comparisons of inequality are generally plagued by problems of poor reliability, lack of coverage, and inconsistent methodology. ${ }^{4}$ We rely on inequality data from the latest World Bank Povcal database constructed by Chen and Ravallion (2004, 2007) for a large number of developing countries. This database uses a substantially more rigorous approach to filtering the individual income and consumption data for differences in quality than other commonly used databases, which rely on more mechanical approaches to combine data from multiple sources and render them somewhat less reliable for cross-country studies. ${ }^{5}$ The Povcal database has been supplemented with data from the Luxembourg Income Study (LIS) database, which provides high-quality coverage for advanced economies, and the resulting full sample allows for more accurate within- and cross-country comparisons than are available elsewhere. The end result is a unique data set that include 51 countries (20 developed and 31 developing) over 1981-2003 that allows us to more comprehensively document inequality facts across a

\footnotetext{
${ }^{3}$ The data set used in the study is available in its entirety via the Internet at www.chrispapageorgiou.com/.

${ }^{4}$ Problems with such data are discussed in Atkinson and Bourguignon (2000), Atkinson and Brandolini (2001), and Deaton and Zaidi (2002).

${ }^{5}$ This database is available via the Internet at iresearch.worldbank.org/PovcalNet. Other databases include, for example, Deininger and Squire (1996) and the World Income Inequality Database (2005), which includes an update of the Deininger-Squire database; the Luxembourg Income Study; and a large number of data series from central statistical offices and research studies.
} 
large number of countries. ${ }^{6}$ The average number of time-series observations per panel is around 5,50 percent of the countries have five or fewer observations, and the maximum number of observations per country is 14 . Gini coefficients for all 20 developed economies in the sample were constructed using income survey data, while Gini coefficients for 16 out of 31 developing economies use consumption survey data. ${ }^{7}$ Since income and consumption surveys are not conducted annually, the estimations use an unbalanced panel with observations included only for years for which actual data are available. One unique feature of our data set is that no extrapolation was used.

Given limitations of data availability, the analysis in this paper uses inequality data based on both income and expenditure surveys. Mixing these two concepts makes a comparison of levels of inequality across countries and regions potentially misleading. In general, consumption-based Gini indices tend to show lower inequality and are more commonly used in developing countries in which higher rates of self-employment in business or agriculture (where income fluctuates throughout the year) make measurement of incomes difficult. Among other causes, lower measures of consumptionbased inequality can result from consumption smoothing across time and greater measurement error for incomes (for example, Ravallion and Chen, 1996; Deaton, 2005).

When comparing income and consumption-based Gini indices, meticulous attention to concepts, definitions, and the details of survey methodology is required to improve comparability, and the World Bank's Povcal database used to construct our data set goes further than other databases in doing this (see Chen and Ravallion, 2004). The database was created using primary data from nationally representative surveys with sufficiently comprehensive definitions of income or consumption. Attempts were made to ensure survey comparability over time within countries, although crosscountry and within-country comparisons are still not without problems because in many cases it was not possible to correct for differences in survey methods. A portion of our data set was obtained from an additional thorough screening and "cleaning up" of the Povcal database to further enhance consistency and comparability of income and consumption data (of course with the cost of losing a substantial amount of observations).

Based on observed movements in Gini coefficients shown in the top panel of Figure 1, inequality has risen in all but the low-income country aggregates over the past two decades, although there are significant regional and country differences. ${ }^{8}$ In addition, while inequality has risen in developing Asia,

\footnotetext{
${ }^{6}$ Although we are not the first to present income inequality patterns using cross-country data, the limited previous studies have presented only fragmented evidence on cross-country inequality patterns based on substantially smaller sets of countries for a shorter time horizon and more questionable data quality.

${ }^{7}$ See the appendix for a list of countries included in the estimation.

${ }^{8}$ Income country groups are defined in the Appendix.
} 
Figure 1. Income Inequality Within Income Country Groups and Selected Countries
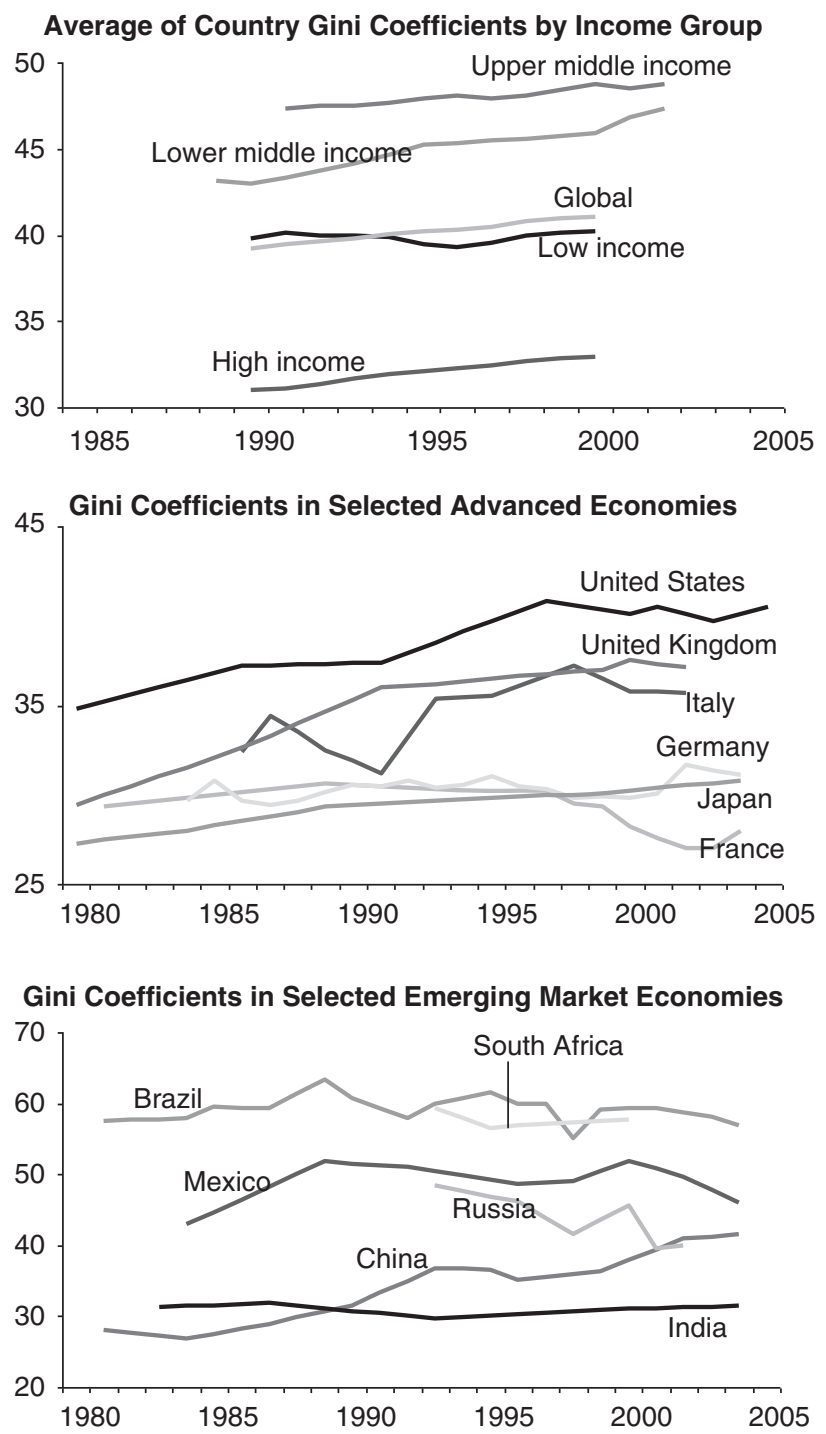

Notes: Income country groups are defined in the Appendix. Trends after 2000 are based on earnings data for full-time, year-round workers. Trends for pre-1992 Germany are based on data for West Germany.

emerging Europe, Latin America, the Newly Industrialized Economics, and the advanced economies over the past two decades, it has declined in some sub-Saharan African countries. The middle panel of Figure 1 illustrates that among the largest advanced economies, inequality appears to have declined only in France, whereas among the major emerging market countries 
Figure 2. Income Shares Within Income Country Groups

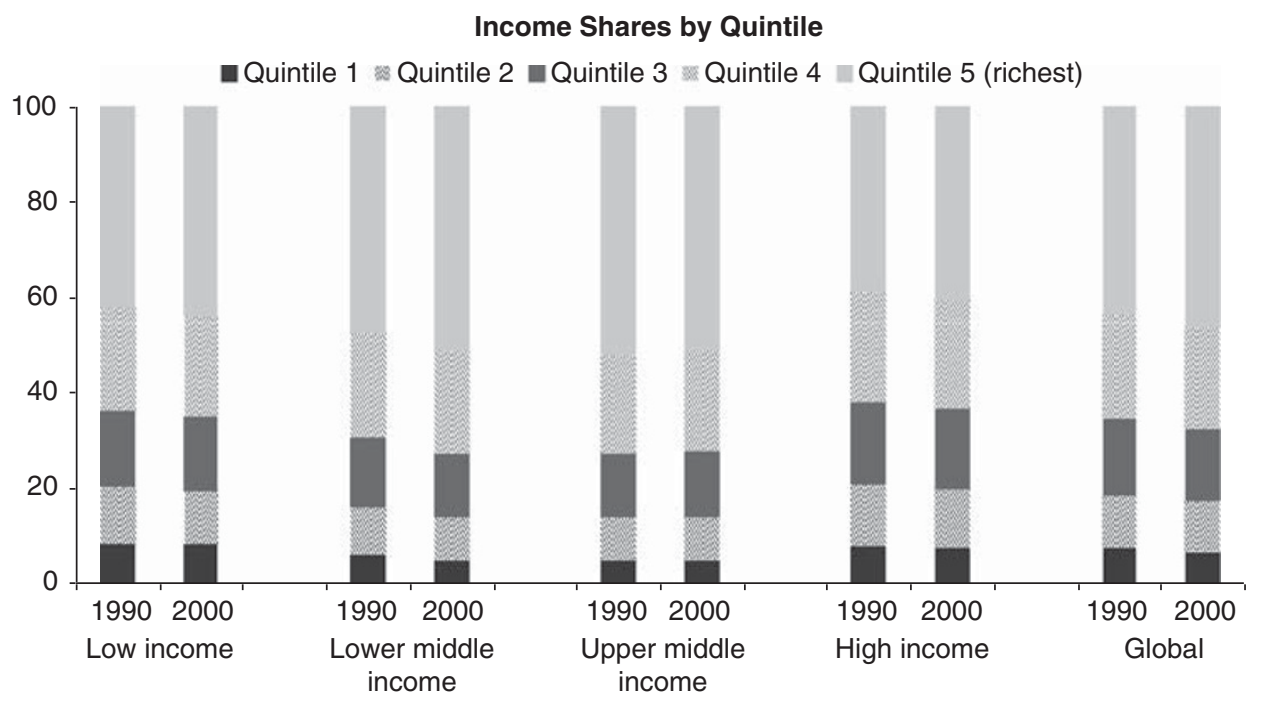

Note: Income country groups are defined in the appendix.

(bottom panel), trends are more diverse, with sharply rising inequality in China, little change in India, and falling inequality in Brazil.

Perhaps a more detailed picture of inequality is revealed by examining income shares for different country groups, presented in Figure 2. Overall, changes in income shares by quintile (successive subsets with each containing 20 percent of the population) across income levels mirror the evidence on inequality from Gini coefficients. However, the data show that rising Gini coefficients are explained largely by the increasing share of the richer quintiles at the expense of middle quintiles, whereas the income share of the poorest quintile (1) changes little. This is consistent with the idea that inequality has increased in the upper part of the distribution in most of our panel of 51 countries - this fact was emphasized for the United States by Autor, Katz and Kearney (2008) and for the United Kingdom by Machin and Van Reenen (2007). Furthermore, looking at average income levels across quintiles, real per capita incomes have risen across virtually all income and regional groups for even the poorest quintiles (Figure 3 shows per capita income by quintile in selected regions). Across all income levels, the evidence therefore suggests that in an absolute sense the poor are no worse off (with the exception of a few postcrisis economies), and in most cases significantly better off, during the most recent phase of globalization.

In summary, two broad facts emerge from the evidence. First, over the past two decades, income growth has been positive for all quintiles in virtually all regions and all income groups during the recent period of globalization. At the same time, however, income inequality has increased 
Figure 3. Income by Quintile in Selected Regions
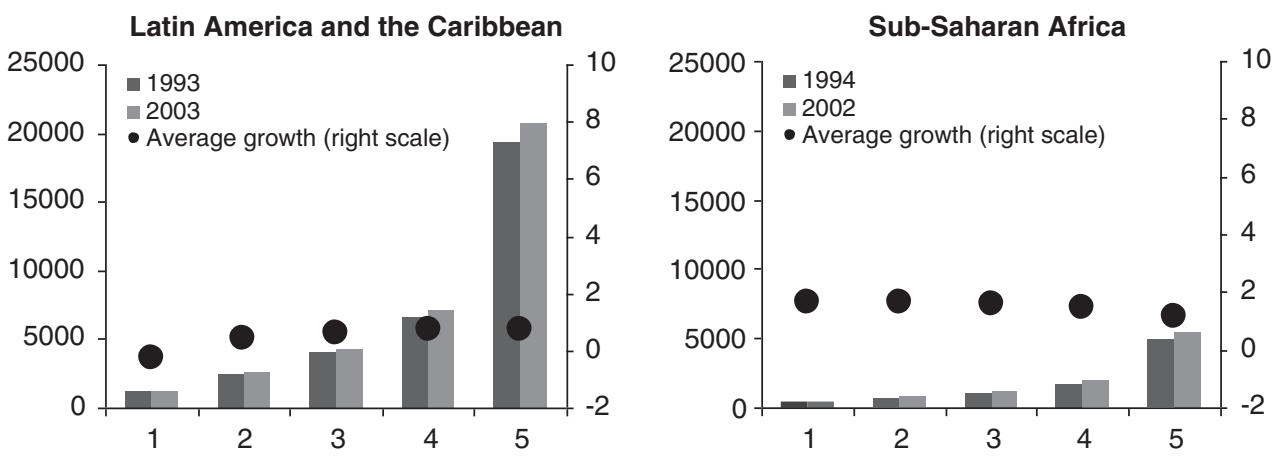

Central and Eastern Europe

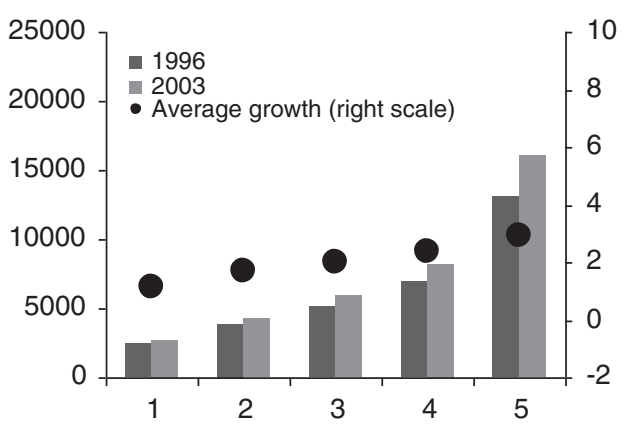

Commonwealth of Independent

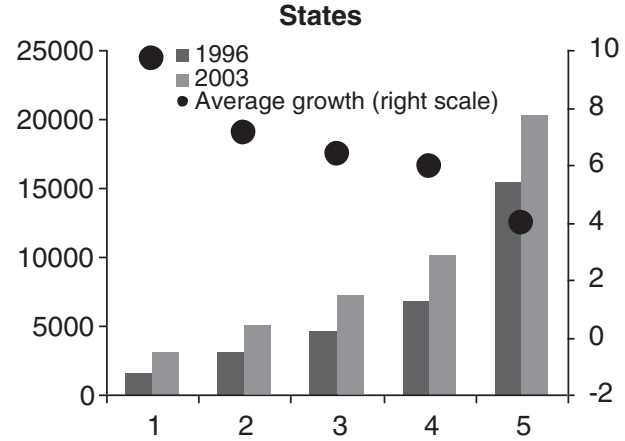

Developing Asia
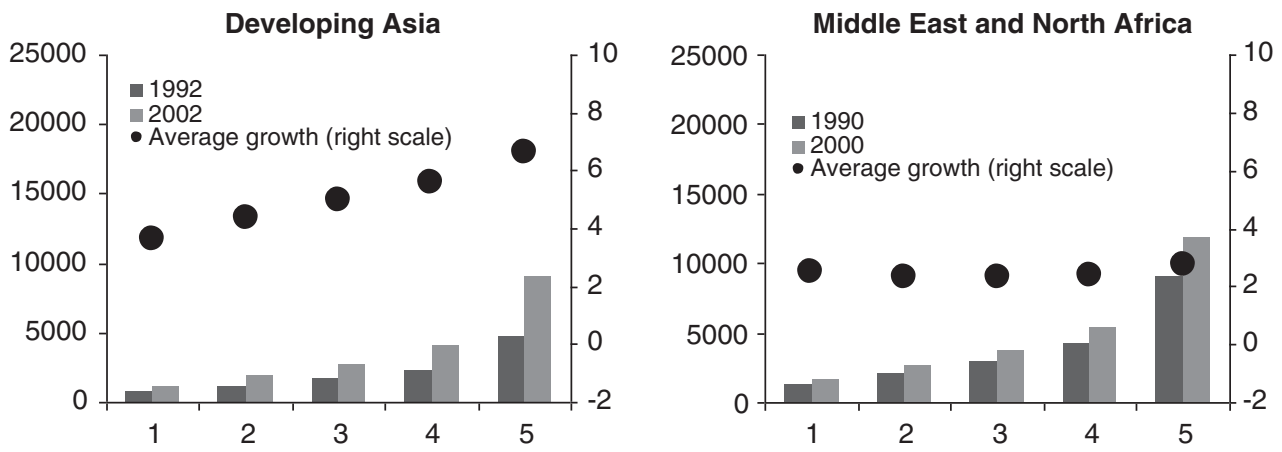

Note: Income or consumption share data are applied to per capita real GDP levels from PWT 6.2 to calculate per capita income by quintile.

mainly in middle- and high-income countries, and less so in low-income countries. This recent experience seems to be a clear change in course from the general decline in inequality in the first half of the twentieth century, and the perception that East Asia's rapid growth during the 1960s and 1970s was achieved while maintaining inequality at relatively low levels. It must be emphasized, however, that comparison of inequality data across decades is 
Figure 4. Trade Liberalization Within Income Country Groups
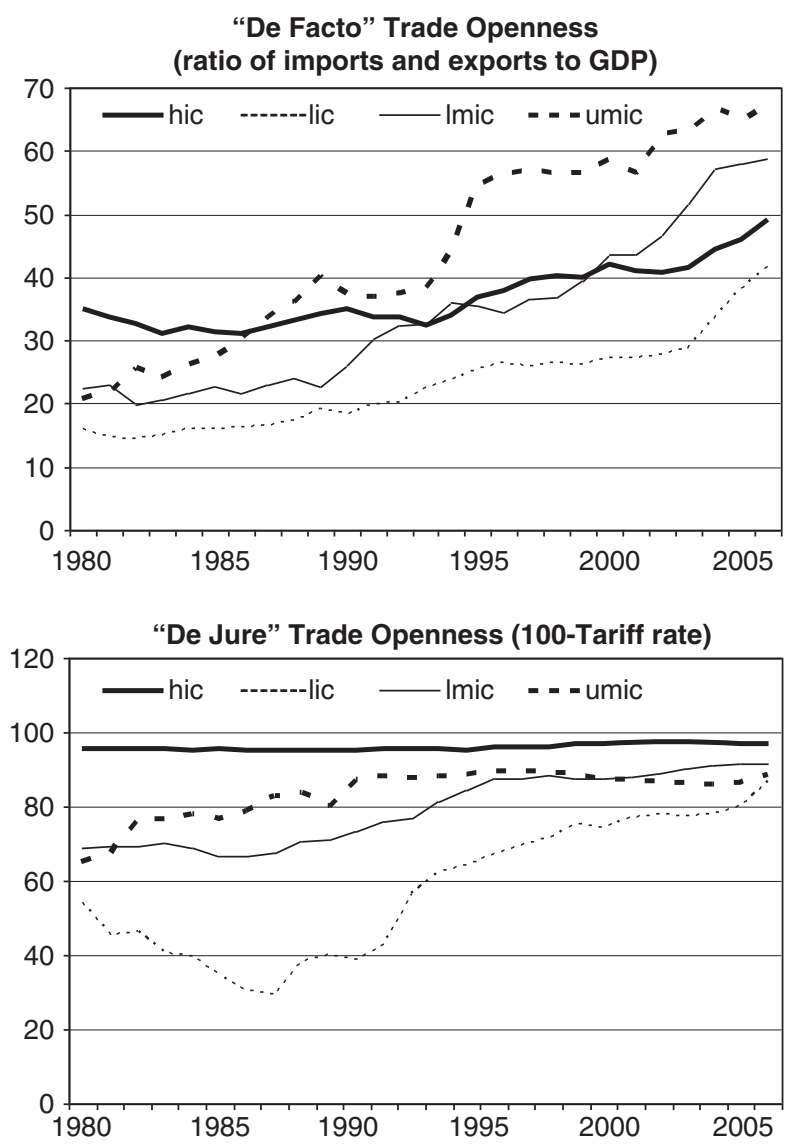

Notes: Income country groups are defined in the Appendix. hic =high income countries, lic $=$ low income countries, lmic $=$ low-middle income countries, and umic $=$ upper-middle income countries. Tariff rates are calculated as the average of the effective rate (ratio of tariff revenue to import value) and of the average unweighted tariff rates.

fraught with difficulty, in view of numerous caveats about data accuracy and methodological comparability.

\section{Trade Openness, Financial Openness, and Technological Progress}

The volume of world trade has grown five times in real terms since 1980, and trade share of world GDP has risen from 36 to 55 percent over this period (top panel of Figure 4). A similar picture emerges when trade openness is measured using tariff rates (bottom panel of Figure 4). Trade integration accelerated in the 1990s, as former Eastern bloc countries integrated into the global trading system and as developing Asia-one of the most closed regions to trade in 1980-progressively dismantled barriers to trade. 
However, it is noteworthy that all groups of emerging market and developing countries, when aggregated by income group (or by region), have been catching up with or surpassing high-income countries in their trade openness, reflecting the widespread convergence of low- and middle-income countries' trade systems toward the traditionally more open trading regimes in place in advanced economies.

Financial globalization has also proceeded at a very rapid pace over the past two decades. Total cross-border financial assets have more than doubled, from 58 percent of global GDP in 1990 to 131 percent in 2004. The advanced economies continue to be the most financially integrated, but other regions of the world have progressively increased their cross-border asset and liability positions (top panel of Figure 5). However, de jure measures of capital account openness present a mixed picture, with developing economies showing little evidence of convergence to the more open capital account regimes in advanced economies, which have continued to liberalize further (bottom panel of Figure 5). ${ }^{9}$

Of note, the share of FDI in total liabilities has risen across all emerging markets - from 17 percent of their total liabilities in 1990 to 38 percent in 2004 - and far exceeds the share of portfolio equity liabilities, which rose from 2 to 11 percent of total liabilities over the same period. Not surprisingly, the share of international reserves in cross-border assets has also risen, reflecting the accumulation of reserves among many emerging market and developing countries in recent years.

At the same time technological development, as measured (in our study) by the share of information and communications technology (ICT) capital in the total capital stock, has risen rapidly over the past 20 years across all income levels. As shown in Figure 6 the sharp increase in the ratio of ICT capital to total capital is predominantly driven by high income (advanced) economies. While the rest of the economies show an increase in our measure of technology as well, it is certainly much less pronounced. ${ }^{10}$ This is quite important in our analysis as technological progress is going to play a key role in explaining much of the observed rise in cross-country inequality. It is worth noting here that we acknowledge the possibility that trade may induce technological shifts and specifically greater investment in ICT (see Bloom, Draca, and Van Reenen, 2011). Therefore, using investment in ICT as a proxy for technology may wrongly assign the effects of trade to effects of technology. While imperfect, our measure of ICT capital obtained from

\footnotetext{
${ }^{9}$ Both de facto and de jure measures have advantages and disadvantages, and are typically seen as complements rather than substitutes in empirical studies. See Kose and others (2009) for a discussion.

${ }^{10}$ It is worth noting that the slower growth of our technology measure in upper-middle income countries is explained by a sharp increase in other forms of capital especially after 1995; that is, ICT capital increased, but total capital increased at a similar rate. We thank a referee for making this observation.
} 
Figure 5. Financial Liberalization Within Income Country Groups

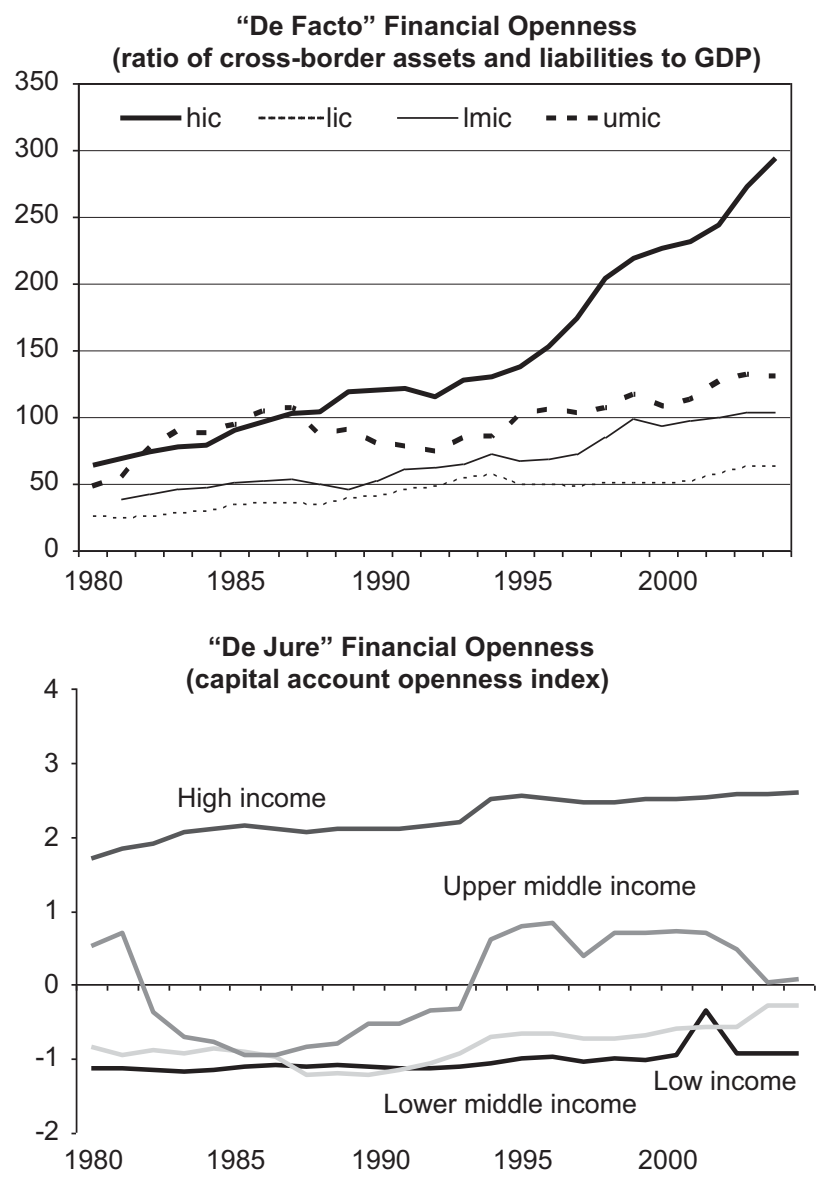

Notes: Income country groups are defined in the appendix. hic $=$ high income countries, lic $=$ low income countries, lmic $=$ low-middle income countries, and umic $=$ upper-middle income countries. De jure financial openness, measuring a country's degree of capital account openness, is an index based on principal components extracted from disaggregated capital and current account restriction measures constructed by Chinn and Ito (2006). As with all principal component analysis the resulting index is computed using binary indicators and thus the unit of the measure can only be interpreted in relative terms.

Jorgenson and $\mathrm{Vu}$ (2005) is considered a reasonable proxy of technology and used widely in the technology-growth empirical literature.

\section{Channels Through Which Globalization Affects Inequality}

This section discusses the channels through which the globalization of trade and finance could affect the distribution of incomes within a country, setting the stage for the empirical analysis that follows.

The principal analytical link between trade liberalization and income inequality provided by economic theory is derived from the Stolper-Samuelson 
Figure 6. Technological Development Within Income Country Groups

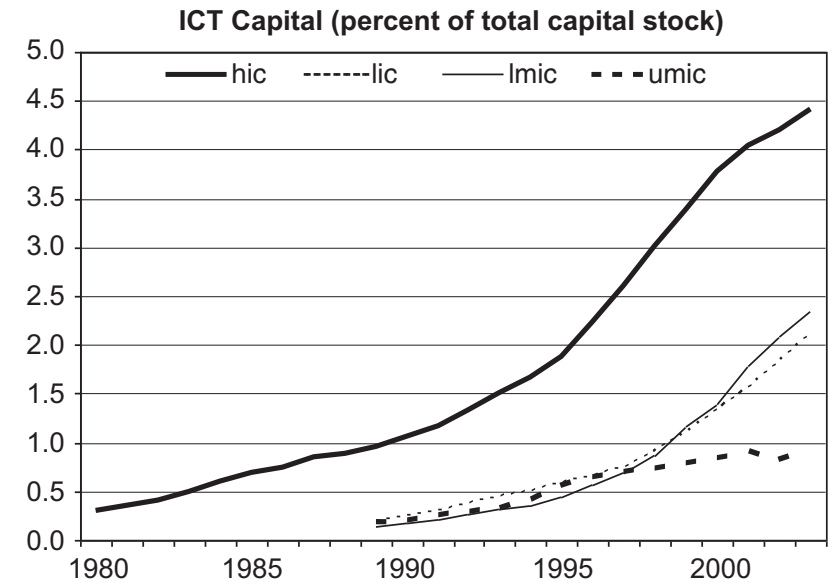

Notes: Income country groups are defined in the appendix. hic $=$ high income countries, lic $=$ low income countries, $\operatorname{lmic}=$ low-middle income countries, and umic $=$ upper-middle income countries. ICT data are from Jorgenson and Vu (2005).

theorem resulting from the Heckscher-Ohlin model: it implies that in a two-country two-factor framework, increased trade openness (through tariff reduction) in a developing country where low-skilled labor is abundant would result in an increase in the wages of the low-skilled workers and a reduction in the compensation of the high-skilled workers, leading to a reduction in income inequality (see Stolper and Samuelson, 1941). After tariffs on imports are reduced, the price of the (importable) high-skill intensive product declines and so does the compensation of the scarce high-skilled workers, while the price of the (exportable) low-skill intensive good for which the country has relatively abundant factors and the compensation of low-skill workers both increase. For an advanced economy where high-skill factors are relatively abundant, the reverse would hold, with an increase in openness leading to higher inequality.

The implications of the Stolper-Samuelson theorem, and in particular the ameliorating effects of trade liberalization on income inequality in developing countries, have been extensively studied but generally not been verified in economy-wide studies. Winters, McCulloch, and McKay (2004) provide an excellent survey of the evidence and demonstrate that "there can be no simple general conclusion about the relationship between trade liberalization and poverty." Albeit this qualification, the paper broadly supports the theoretical presumption that trade liberalization will be poverty-alleviating and lends no support to the position that trade liberalization has an adverse effect on inequality.

A particular challenge has been to explain the increase in skill premium between skilled and unskilled workers observed in most developing countries. 
This has led to various modifications to the Heckscher-Ohlin model, including the introduction of multiple countries where poor (rich) countries may also import low-skill (high-skill) intensive goods from other poor (rich) countries; the introduction of a continuum of goods, implying that what is low skill-intensive in the advanced economy will be relatively highly skillintensive in a less developed country (see Feenstra and Hanson, 1996); and the introduction of intermediate imported goods used for the skill-intensive product. However, these extensions have themselves presented additional challenges for empirical testing.

As a consequence of these challenges an alternative literature has emerged arguing that the Heckscher-Ohlin model is inconsistent with recent inequality experience around the world, not just related to the fact that inequality increased in developing countries, but also along multiple other dimensions - for example, factor reallocation seems to occur primarily within rather than across sectors (Berman, Bound, and Grilïches, 1994); small change in the prices of unskilled goods relative to skilled goods accompany large changes in the skill premium (Lawrence and Slaughter, 1993). Recent theoretical and empirical studies try to rethink the effects of trade on inequality in the context of heterogeneous firms and provide quite different insights from the Heckscher-Ohlin model. Recent contributions include Egger and Kreickemeier (2009), Verhoogen (2008), and Yeaple (2005), just to name a few.

Difficulties in explaining observed increases in inequality by betweensector shifts gave rise to a parallel and competing literature showing evidence of other nontrade factors such as skill-biased technical change. Put differently, alternative explanations for rising skill premiums are based on the notion that technological change is inherently skill-biased, attributing the observed increases in inequality (including in advanced economies) to exogenous technology shocks (see for example Berman, Bound, and Griliches, 1994; Berman, Bound, and Machin, 1998). Another explanation of how the spread of technology may affect inequality is that technology may increase capital intensity in production, thereby increasing the returns to capital and the relative income of capital owners (see Krusell and others, 2000, for an analysis of the impact of capital-skill complementarity in the United States). Any empirical estimation of the overall effects of globalization therefore needs to explicitly account for changes in technology in countries, in addition to standard trade-related variables.

An additional important qualification to the implications deriving from the Stolper-Samuelson theorem relate to its assumption that labor and capital are mobile within a country but not internationally. If capital is assumed to be mobile across borders, then the implications of the theorem are weakened substantially. This channel would appear to be most evident for FDI, which is often targeted at high-skilled sectors in the host economy (see Cragg and Epelbaum, 1996). Moreover, what appears to be relatively highly skill-intensive inward FDI for a less developed country may appear relatively low skill-intensive outward FDI for the advanced economy. 
An increase in FDI from advanced to developing countries could thus increase the relative demand for skilled labor in both countries, increasing inequality in both the advanced economy and the developing country. The empirical evidence on these channels has provided mixed support for this view, with the impact of FDI seen as contributing to inequality, at least in the short run, or inconclusive.

In addition to FDI, there are other important channels through which capital flows across borders, including cross-border bank lending, portfolio debt, and equity flows. Within this broader context, some have argued that greater capital account liberalization may increase access to financial resources for the poor, while others have suggested that by increasing the likelihood of financial crises greater financial openness may disproportionately hurt the poor. Some recent research has found that the strength of institutions plays a crucial role: in the context of strong institutions, financial globalization may allow better consumption smoothing and lower volatility for the poor, but where institutions are weak, financial access is biased in favor of those well-off and the increase in finance from tapping global and not just domestic savings may further exacerbate inequality. ${ }^{11}$ Thus, the composition of financial flows may matter, and the net impact also be influenced by other factors such as the quality of financial sector institutions. Overall, and taking a longer perspective, the impact of non-FDI flows would depend on the extent to which it is accompanied by domestic financial development that broadens the access to finance rather than serves to deepen it. If financial flows make resources available to a broader cross-section of the work-force, they would serve to reduce inequality by allowing investment in skills and human capital. However, if they make more financial resources available to those who already have capital and collateral, this would likely exacerbate inequality.

It should be noted that the link between income inequality and the two channels discussed above, that is, through trade liberalization and skillbiased technological change, is argued in the literature to operate through labor income. In other words, these channels can drive a wedge between lowand high-skill workers' income as discussed above. Financial globalization and the ability to access cross-border finance, on the other hand, would be expected to operate through capital owners' income. To the extent that financial globalization allows agents to borrow and invest more easily in the production of goods and services or in human capital, this would be expected to boost the future incomes of these agents more than those who are unable to access such financing.

In summary, analytical considerations suggest that any empirical analysis of the distributional consequences of globalization must take into account

${ }^{11}$ While Demirgüç-Kunt and Levine (2007) argue that financial development is more positive for the poorest segment of the population, primarily through its positive effect on overall growth, Claessens and Perotti (2007) find that the outcome can be different as most of the benefits of financial reforms are captured by a small elite. 
both trade and the various channels through which financial globalization operates, and also account for the separate impact of technological change.

\section{Empirical Analysis}

In this section we use cross-country estimation to investigate how much of the rise in inequality seen in developing and high-income countries in recent decades can be attributed to increased globalization, and how much to other factors, such as the spread of technology and domestic constraints on equality of opportunity. While country studies can certainly take advantage of more disaggregated and more detailed data to study the effects of globalization on inequality, they cannot capture the broad relationship as each study focuses instead on some parameters of particular interest.

\section{Specification}

In contrast to most existing studies that focus on within-country variation in inequality in a particular country, ${ }^{12}$ this study is unique because it uses a large panel of advanced and developing countries. The analysis relates the Gini coefficient to various measures of globalization and a number of control variables including technological progress. Globalization measures distinguish between trade and financial openness and include both "de facto" and "de jure" measures. Specifically, trade openness is measured by the average tariff rate ("de jure" measure), and the ratios of both non-oil exports and non-oil imports to GDP ("de facto" measures). Financial openness is measured by the Chinn-Ito index of capital account openness ("de jure" measure), the ratios of various types of financial liabilities (FDI, portfolio equity, and debt) to GDP, and the stock of FDI assets expressed as a percentage of GDP ("de facto" measures). ${ }^{13}$ The latter, which is closely associated to offshore outsourcing, may be particularly relevant to measure the impact of globalization on inequality in advanced economies, while its value is minimal for most developing and emerging market countries. It is important to caution, however, that offshore outsourcing can be viewed as a measure of trade openness as well (see, for example, Feenstra and Hanson, 1996), and the effect of offshoring on inequality could be interpreted as the effect of trade.

The analysis also includes a number of control variables that can be important in determining how inequality changes in countries over time and that have seen significant changes in recent years. These include technological development, measured by the share of ICT capital in the total

\footnotetext{
${ }^{12}$ See Goldberg and Pavcnik (2007) for a survey of theoretical and empirical research on the distributional effects of globalization in specific countries.

${ }^{13}$ The Chinn-Ito measure has recently been under a fair amount of criticism primarily stemming from the subcomponents used in its construction. A conceptually superior alternative is the new Schindler index (Schindler, 2008); however, we were not able to use it in our estimation because of its short time-series dimension starting after 1995.
} 
capital stock, access to education, measured by the average years of education in the population ages 15 and older, and the share of this population with at least a secondary education, sectoral shares of employment, measured by the shares of employment in agriculture and in industry, and domestic financial development, measured by the ratio of private credit to GDP.

To the extent that technological change favors those with higher skills and exacerbates the "skills gap," it could adversely affect the distribution of income in both developing and advanced economies by reducing the demand for lower-skill activities and increasing the premium for higher-skill activities and returns on capital (see, for example, Birdsall, 2007). As shown in Figure 6, ICT capital has risen rapidly over the past 20 years across all income country groups. For a given level of technology, greater access to education would be expected to reduce income inequality by allowing a greater share of the population to be engaged in high-skill activities. Both educational variables considered in the analysis have tended to increase across all regions, but with considerable cross-country variation.

In developing countries, a move away from the agricultural sector to industry is expected to improve the distribution of income by increasing the income of low-earning groups. Similarly, an increase in the relative productivity of agriculture is expected to reduce income disparities by increasing the income of those employed in this sector. In fact this channel was one of Kuznets' (1955) original arguments for his inverted-U relationship between inequality and development. Briefly, with a fixed wage differential, a movement of labor between the two sectors will tend to raise inequality over some region of the employment share and reduce it beyond it, as the relative sizes of the two groups change (see Robinson, 1976). ${ }^{14}$ The sectoral distribution of employment is measured by the shares of employment in agriculture and in industry.

Even though financial development may reduce income inequality by increasing access to capital for the poor (see Beck, Demirgüç-Kunt, and Levine, 2007), this depends on the quality of institutions in a given country. In the context of weak institutions, the benefits of financial deepening may accrue disproportionately to the rich which have higher collateral and/or income, further exacerbating initial inequality in access to finance.

Ideally, our estimation methodology should be motivated by a particular theoretical framework, even if the estimation is not structural. However, there is no formal theory that incorporates the effects of trade and financial globalization, and technology in a model of income inequality.

\footnotetext{
${ }^{14}$ For a comprehensive review of the empirical literature testing Kuznets' hypothesis see Fields (2001) and for a recent contribution using cross-country panel estimation, similar to this paper, see Angeles (2010).
} 
Therefore, our estimation will not be linked directly to any one existing theory, but will incorporate key ingredients of the prominent theories in the literature.

The empirical analysis is based on the following fixed-effects specification ${ }^{15}$ :

$$
\begin{aligned}
\ln (\text { GINI })_{i t}= & \alpha(\text { Trade Globalization Variables })_{i t} \\
& +\beta\left({\text { Financial Globalization Variables })_{i t}}\right. \\
& +\gamma(\text { Technology })_{i t}+\delta(\text { Controls })+\eta_{i}+\theta_{t}+\varepsilon_{i t} .
\end{aligned}
$$

where globalization is divided between various measures of trade openness and financial openness and technology is proxied by $\ln \left(K_{I C T} / K\right)$, where $K_{I C T}$ is the stock of ICT capital, and $K$ is physical capital. A vector of additional control variables includes, $\ln (C R E D I T / Y)$ where $C R E D I T$ is defined as credit to the private sector by deposit money banks and other financial institutions, $P O P_{S H}$ defined as the share of population aged 15 and over with secondary or higher education, $H$, the average years of education in the population aged 15 and over, $\ln \left(E_{A G R} / E\right)$ and $\ln \left(E_{I N D} / E\right)$, where $E_{A R G}$ and $E_{I N D}$ are employment in agriculture and industry and $E$ is total employment. The terms $\eta_{i}$ represents a full set of country dummies, $\theta_{t}$ a full set of time dummies, and $\varepsilon_{i t}$ captures all the omitted factors.

Country fixed effects allow us to focus on within-country changes instead of cross-country level differences. In addition, time dummies are included to capture the impact of common global shocks such as business cycles or growth spurts. The resulting baseline model is estimated using fixed effects panel regressions with standard errors clustered at the country level.

Before moving on to reporting results, some cautionary remarks with regards to our estimation specification are warranted. Although our panel regression estimation has the advantage of controlling for country fixed effects (particularly important in our analysis given that in some countries inequality is measured using income data while in other countries using consumption data), there are also some concerns: First, using changes rather than level data may result in magnified measurement error (Bound and Krueger, 1991). In our estimation, using deviations rather than levels is necessary given that merging consumption and income data sets is significantly more problematic than the potential magnification error. Second, we acknowledge that while our estimation approach may successfully suppress business cycle effects, this may not be entirely desirable in the present study given that part of the variation shown in the illustrative part of the paper may be coming from business cycle. Third, an alternative strategy

\footnotetext{
${ }^{15}$ Using the logarithm of the Gini (rather than the Gini itself) makes this bounded variable behave more like a normally distributed variable and hence more amenable to ordinary least squares estimation. Robustness of the results was confirmed also using a logistic transformation of the Gini coefficient (making the variable completely unbounded).
} 
is to try to identify regressions based on between-country variation. While subsequent robustness analysis reports some results from between-estimator regressions, it is important to note that such strategy is subject to the problem Brock and Durlauf (2001) called the "open-endedness" of the regression specification, and the resulting omitted variable problem that can be as enormous in this literature as it is in the growth regression literature.

\section{Baseline Results}

We first use a parsimonious specification ("Summary model"; column 1 of Table 1) with the standard measures of trade openness: non-oil exports + non-oil imports/GDP, 100-average tariff rate; and financial openness: cross-border assets + liabilities/GDP, capital account openness index. The estimation of the Summary model for the whole sample of countries shows that globalization has a significant impact on inequality. Interestingly, trade and financial globalization appear to have opposite effects: an increase in trade openness is found to reduce inequality as does a reduction in average tariff rates, while financial openness, as measured by cross-border assets and liabilities, increases inequality. While tariff rates are significant at the 5 percent level, the trade and financial openness effects are only significant at the 10 percent level.

Next we disaggregate the de facto measures of trade and financial openness into subcomponents ("Full model"; column 2 of Table 1). Trade openness is replaced by the individual import and export shares of GDP, while financial openness is decomposed into the outward FDI stock, the inward FDI stock, the inward portfolio equity stock and the inward debt stock. Neither export- nor import-to-GDP are significant at conventional levels; these two variables are in fact highly correlated (at 87 percent). On the financial openness side, the variable that shows significance (at the 5 percent level) is the ratio of inward FDI stock to GDP.

We further modify the estimation model, after a joint test shows that imports and other components of financial openness (with the exception of inward FDI) are insignificant. The model re-estimated dropping imports and the insignificant measures of financial globalization constitutes our "Benchmark model" (column 3 of Table 1). The coefficient on exports implies that a one standard deviation increase in the export-to-GDP ratio from its sample mean would reduce inequality approximately by 3.4 percent. Similarly, a one standard deviation decrease in tariffs would reduce inequality by 2.6 percent while a one standard deviation increase in inward FDI would increase inequality by 2.9 percent.

To better understand the inequality-reducing impact of exports, the export-to-GDP ratio is split by sector of origin (agriculture, manufacturing, and services) (column 4 of Table 1). We find that it is the agricultural component of exports that is especially important to reduce inequality. The effects of agriculture, manufacturing, and services exports are statistically not significantly different from one another, but agricultural exports have the 
Table 1. Income Inequality Panel Regressions (Dependent Variable: Natural Logarithm of Gini)

\begin{tabular}{|c|c|c|c|c|c|c|}
\hline & (1) & (2) & (3) & (4) & (5) & (6) \\
\hline Model specification & $\begin{array}{l}\text { Summary } \\
\text { model }\end{array}$ & $\begin{array}{l}\text { Full } \\
\text { model }\end{array}$ & $\begin{array}{l}\text { Benchmark } \\
\text { model }\end{array}$ & $\begin{array}{l}\text { Sectoral } \\
\text { exports }\end{array}$ & $\begin{array}{l}\text { Sectoral } \\
\text { productivity }\end{array}$ & $\begin{array}{c}\text { IV } \\
\text { estimation }\end{array}$ \\
\hline \multicolumn{7}{|l|}{ Trade globalization } \\
\hline $\begin{array}{l}\text { Ratio of exports and } \\
\text { imports to GDP }\end{array}$ & $\begin{array}{l}-0.058 \\
(1.83)^{*}\end{array}$ & & & & & \\
\hline Export-to-GDP ratio & & $\begin{array}{r}-0.061 \\
(1.49)\end{array}$ & $\begin{array}{l}-0.056 \\
(2.02)^{* *}\end{array}$ & & $\begin{array}{l}-0.050 \\
(1.77)^{*}\end{array}$ & $\begin{array}{l}-0.054 \\
(1.67)^{*}\end{array}$ \\
\hline Agricultural exports & & & & $\begin{array}{l}-0.030 \\
(2.09)^{* *}\end{array}$ & & \\
\hline Manufacturing exports & & & & $\begin{array}{r}0.006 \\
(0.31)\end{array}$ & & \\
\hline Service exports & & & & $\begin{array}{r}-0.004 \\
(0.20)\end{array}$ & & \\
\hline Import-to-GDP ratio & & $\begin{array}{c}0.004 \\
(0.11)\end{array}$ & & & & \\
\hline 100 minus tariff rate & $\begin{array}{l}-0.002 \\
(2.59)^{* *}\end{array}$ & $\begin{array}{l}-0.002 \\
(2.89)^{* * *}\end{array}$ & $\begin{array}{l}-0.003 \\
(3.17)^{* * *}\end{array}$ & $\begin{array}{l}-0.003 \\
(3.27)^{* * *}\end{array}$ & $\begin{array}{l}-0.003 \\
(3.12)^{* * *}\end{array}$ & $\begin{array}{l}-0.003 \\
(3.78)^{* * *}\end{array}$ \\
\hline \multicolumn{7}{|l|}{ Financial globalization } \\
\hline $\begin{array}{l}\text { Ratio of cross-border } \\
\text { assets and liabilities to } \\
\text { GDP }\end{array}$ & $\begin{array}{c}0.035 \\
(1.79)^{*}\end{array}$ & & & & & \\
\hline $\begin{array}{l}\text { Ratio of inward FDI } \\
\text { stock to GDP }\end{array}$ & & $\begin{array}{l}0.042 \\
(2.38)^{* *}\end{array}$ & $\begin{array}{l}0.042 \\
(2.48)^{* *}\end{array}$ & $\begin{array}{l}0.040 \\
(2.37)^{* *}\end{array}$ & $\begin{array}{l}0.037 \\
(2.06)^{* *}\end{array}$ & $\begin{array}{c}0.032 \\
(1.81)^{*}\end{array}$ \\
\hline $\begin{array}{l}\text { Ratio of inward portfolio } \\
\text { equity stock to GDP }\end{array}$ & & $\begin{array}{r}-0.000 \\
(0.18)\end{array}$ & & & & \\
\hline $\begin{array}{l}\text { Ratio of inward debt } \\
\text { stock to GDP }\end{array}$ & & $\begin{array}{c}0.005 \\
(0.27)\end{array}$ & & & & \\
\hline $\begin{array}{l}\text { Ratio of outward FDI } \\
\text { stock to GDP }\end{array}$ & & $\begin{array}{r}0.001 \\
(0.43)\end{array}$ & & & & \\
\hline $\begin{array}{l}\text { Capital account openness } \\
\text { index }\end{array}$ & $\begin{array}{r}0.000 \\
(0.02)\end{array}$ & $\begin{array}{r}-0.002 \\
(0.33)\end{array}$ & & & & \\
\hline \multicolumn{7}{|l|}{ Technology } \\
\hline $\begin{array}{l}\text { Share of ICT in total } \\
\text { capital stock }\end{array}$ & $\begin{array}{l}0.075 \\
(2.57)^{* *}\end{array}$ & $\begin{array}{l}0.057 \\
(1.90)^{*}\end{array}$ & $\begin{array}{c}0.054 \\
(1.95)^{*}\end{array}$ & $\begin{array}{l}0.053 \\
(2.05)^{* *}\end{array}$ & $\begin{array}{l}0.050 \\
(2.17)^{* *}\end{array}$ & $\begin{array}{l}0.068 \\
(2.70)^{* * *}\end{array}$ \\
\hline \multicolumn{7}{|l|}{ Control variables } \\
\hline $\begin{array}{l}\text { Credit to private sector } \\
\quad(\% \text { of GDP })\end{array}$ & $\begin{array}{l}0.063 \\
(4.66)^{* * *}\end{array}$ & $\begin{array}{l}0.052 \\
(3.68)^{* * *}\end{array}$ & $\begin{array}{l}0.054 \\
(4.08)^{* * *}\end{array}$ & $\begin{array}{l}0.054 \\
(5.13)^{* * *}\end{array}$ & $\begin{array}{l}0.053 \\
(4.55)^{* * *}\end{array}$ & $\begin{array}{l}0.044 \\
(3.58)^{* * *}\end{array}$ \\
\hline $\begin{array}{l}\text { Population share with at } \\
\text { least a secondary } \\
\text { education }\end{array}$ & $\begin{array}{r}0.004 \\
(1.57)\end{array}$ & $\begin{array}{r}0.003 \\
(1.12)\end{array}$ & $\begin{array}{r}0.003 \\
(1.17)\end{array}$ & $\begin{array}{r}0.002 \\
(0.70)\end{array}$ & $\begin{array}{c}0.004 \\
(1.60)\end{array}$ & $\begin{array}{r}0.001 \\
(0.55)\end{array}$ \\
\hline $\begin{array}{l}\text { Average years of } \\
\text { education }\end{array}$ & $\begin{array}{r}-0.298 \\
(1.41)\end{array}$ & $\begin{array}{c}-0.154 \\
(0.76)\end{array}$ & $\begin{array}{r}-0.175 \\
(0.93)\end{array}$ & $\begin{array}{r}-0.147 \\
(0.72)\end{array}$ & $\begin{array}{r}-0.300 \\
(1.51)\end{array}$ & $\begin{array}{r}-0.120 \\
(0.61)\end{array}$ \\
\hline $\begin{array}{l}\text { Agriculture employment } \\
\text { share }\end{array}$ & $\begin{array}{r}0.017 \\
(0.52)\end{array}$ & $\begin{array}{r}0.025 \\
(0.66)\end{array}$ & $\begin{array}{c}0.024 \\
(0.66)\end{array}$ & $\begin{array}{r}0.015 \\
(0.48)\end{array}$ & & $\begin{array}{r}0.033 \\
(0.98)\end{array}$ \\
\hline
\end{tabular}


Table 1 (continued)

\begin{tabular}{|c|c|c|c|c|c|c|}
\hline & (1) & (2) & (3) & (4) & (5) & (6) \\
\hline Model specification & $\begin{array}{c}\text { Summary } \\
\text { model }\end{array}$ & $\begin{array}{l}\text { Full } \\
\text { model }\end{array}$ & $\begin{array}{c}\text { Benchmark } \\
\text { model }\end{array}$ & $\begin{array}{l}\text { Sectoral } \\
\text { exports }\end{array}$ & $\begin{array}{c}\text { Sectoral } \\
\text { productivity }\end{array}$ & $\begin{array}{c}\text { IV } \\
\text { estimation }\end{array}$ \\
\hline $\begin{array}{l}\text { Industry employment } \\
\text { share }\end{array}$ & $\begin{array}{l}-0.100 \\
(2.50)^{* *}\end{array}$ & $\begin{array}{l}-0.116 \\
(2.48)^{* *}\end{array}$ & $\begin{array}{l}-0.112 \\
(3.02)^{* * * *}\end{array}$ & $\begin{array}{l}-0.127 \\
(2.70)^{* * *}\end{array}$ & & $\begin{array}{l}-0.115 \\
(3.21)^{* * *}\end{array}$ \\
\hline $\begin{array}{l}\text { Relative labor } \\
\text { productivity of } \\
\text { agriculture }\end{array}$ & & & & & $\begin{array}{r}-0.028 \\
(0.85)\end{array}$ & \\
\hline $\begin{array}{l}\text { Relative labor } \\
\text { productivity of } \\
\text { industry }\end{array}$ & & & & & $\begin{array}{l}0.133 \\
(2.72)^{* * *}\end{array}$ & \\
\hline Observations & 292 & 288 & 292 & 288 & 283 & 284 \\
\hline$R$-squared (within) & 0.36 & 0.39 & 0.39 & 0.40 & 0.41 & \\
\hline $\begin{array}{l}\text { Kleibergen-Paap test } \\
\quad(p \text {-value })\end{array}$ & & & & & & 0.00 \\
\hline $\begin{array}{l}\text { Hansen } \mathbf{J} \text { statistic } \\
\quad(p \text {-value })\end{array}$ & & & & & & 0.88 \\
\hline
\end{tabular}

Notes: The regressions were estimated using panel regressions with country fixed effects and time dummies. Standard errors are clustered at the country level. $t$-statistics are in parentheses. *denotes significance at the 10 percent level, ${ }^{* *}$ denotes significance at the 5 percent level, ${ }^{* * *}$ denotes significance at the 1 percent level. All explanatory variables are in natural logarithm, except the tariff measure, the capital account openness index, and the population share with at least a secondary education. $\mathrm{FDI}=$ foreign direct investment; $\mathrm{ICT}=$ information and communications technology.

largest coefficient and are statistically significant. The coefficient on exports thus seems to reflect the fact that in many developing countries a lot of the poor are still employed in the agricultural sector, so that an improvement in the export prospects of this sector tends to reduce inequality. Tariff reductions on average also seem to benefit the poor relatively more than the rich, suggesting that on average they affected goods which are disproportionately consumed by the poor and/or formal sectors where the better-off part of the population is employed. The inequality-raising impact of inward FDI, although puzzling at first, appeared to make a lot of sense upon examination of data on the sectoral composition of FDI. These suggest indeed that FDI mostly takes place in relatively higher skill- and technologyintensive sectors, and thereby increases the demand for, and wages of, more skilled workers.

Most of the control variables are also found to be statistically significant and-except for the education variables and the share of agricultural employment - these estimates are broadly robust across different models. First, technological progress and domestic financial deepening both significantly increase inequality. These effects are in line with the discussion above that technological progress increases the demand for skilled workers and that 
the benefits of enhanced financial deepening may disproportionately accrue to the rich, which have more collateral and/or income. The coefficient on technological progress is significant at the 5 percent level in the Summary model and at the 10 percent level in the Full and Benchmark models, while that on domestic financial deepening is significant at the 1 percent level in all three models. Under the Benchmark model the coefficient estimates suggest that a one standard deviation increase in these variables from their mean level would increase inequality by 2.9 percent in the case of technological progress and by 2.8 percent in the case of domestic financial deepening.

Second, the share of agriculture employment tends to increase inequality (though not significantly so), while the share of industry employment reduces it. Assuming that relative labor productivity is an indicator of the size of the intersectoral wage differential (see Bourguignon and Morrisson, 1998; Temple, 2005), we replace the employment shares by measures of relative labor productivity in agriculture and industry (column 5 of Table 1). It is interesting to note, once again, that the coefficient estimates of labor productivity in agriculture and in industry on inequality have opposite signs.

Third, the regression coefficients on education suggest that an increase in the average years of education in the population reduces inequality, presumably because it enables more people to benefit from the opportunities offered by technological progress and FDI. For a given average level of education, however, a larger share of the population with secondary or higher education tends to increase inequality. These coefficients are however imprecisely estimated. This is likely reflecting overlap between some control variables, but also lack of sufficient variation in both education variables within our sample's short time horizon.

To address concerns that inequality may itself influence globalization variables, the export-to-GDP ratio and the ratio of the inward stock of FDI to GDP (the two significant "de facto" measures) were instrumented using their lagged value, the export-weighted real GDP of trade partners (a measure of the demand for the country's exports), and a distance-weighted sum of industrial countries' FDI assets (a measure of the supply of FDI). The results proved robust to allowing for endogeneity in this way (column 6 of Table 1).

The Gini coefficient is known to be sensitive to transfers that displace the rank orders of more individuals thus making it more sensitive to the middle of the distribution than to changes at either the top or the bottom (Kakwani, 1980). Given that our analysis suggests that inequality has increased primarily in the upper part of the distribution, the use of the Gini coefficient may underestimate the increases in inequality, if more weight were to be given to changes in the upper part of the distribution. For this reason and to gain further insight into the impact of globalization on inequality, the Benchmark model was also estimated using the income shares of the five quintiles of the population as dependent variables (Table 2). Most of the results from the estimations using Gini coefficients are confirmed. In line with the changes observed in the income shares of quintiles, the effects on the bottom four 
quintiles are qualitatively similar and in the opposite direction from that on the richest quintile. Export growth is associated with a rise in the income shares of the bottom four quintiles and a decrease in the share of the fifth (that is, the richest) quintile. Similarly, a reduction in the share of agricultural employment is also associated with a rise in the income share of the bottom four quintiles, whereas it has the opposite effect on the income share of the richest quintile (though not significant). The benefits of tariff reduction are mostly concentrated in the income shares of the three bottom quintiles, offset by a decrease in the income share of the top quintile. In contrast, financial globalization, technological progress, and greater financial deepening benefit mainly the income share of the richest 20 percent of the population.

\section{Robustness}

The reported results were further tested for robustness in several ways. First, we examine robustness of our results to "long-difference" estimation, that is, the difference between the latest and the earliest observation for each country. Each country's observation is weighted by the number of years between the latest and earliest observation to give more weight to countries for which inequality could be observed over longer time periods. We do this for the Summary, Full, and Benchmark models (columns 1-3 of Table 3). Although our sample is reduced to only 51 observations, it is shown that, net of trade openness, most coefficient estimates are broadly consistent with those of Table 1, although those of technology and credit are largerpossibly due to the longer run nature of the estimates. The significance of the coefficients is overall quite good, with significant effects for capital account openness, inward FDI, technology, credit, and the industry employment share. Table 3 (columns 4-5) also re-estimates the benchmark model using panel regressions with random effects and between effects (the latter is a regression on group averages). For the between-effect estimation, we chose to include additional controls in the absence of fixed effects, namely initial level of GDP and a dummy variable for consumption-based Gini. The results under both specifications are broadly similar to those in the Benchmark model estimated with panel fixed effects.

While it is challenging to disentangle the effects of technology and globalization, we test the robustness of the estimated coefficients on globalization to dropping the technology variable. In this case, the coefficient on globalization should include its direct effect on inequality as well as its indirect effect on inequality through the technology variable. Conversely, we have also dropped the globalization variables to check the robustness of the estimated coefficient on technology. In support to our findings, Table 4 shows that the estimates are very stable compared with the initial regression that includes globalization and technology variables.

We have also examined robustness of the baseline results over different country groups. In the main regression, it may be overly restrictive to have common coefficients on the globalization variables and technology variables 
Table 2. Quintile Income Shares Regressions (Dependent Variable: Natural Logarithm of Gini)

\begin{tabular}{|c|c|c|c|c|c|c|}
\hline & (1) & (2) & (3) & (4) & (5) & \multirow{2}{*}{$\begin{array}{c}\text { Test All } \\
\text { Coefficients } \\
\text { Equal to Zero } \\
\text { [p-value }]\end{array}$} \\
\hline & Quintile 1 & Quintile 2 & Quintile 3 & Quintile 4 & Quintile 5 & \\
\hline Export-to-GDP ratio & $\begin{array}{l}0.413 \\
(2.35)^{* *}\end{array}$ & $\begin{array}{l}0.593 \\
(3.35)^{* * *}\end{array}$ & $\begin{array}{l}0.677 \\
(3.63)^{* * *}\end{array}$ & $\begin{array}{l}0.467 \\
(2.47)^{* *}\end{array}$ & $\begin{array}{l}-2.122 \\
(3.45)^{* * *}\end{array}$ & $0.02 * *$ \\
\hline 100 minus tariff rate & $\begin{array}{l}0.024 \\
(2.58)^{* * *}\end{array}$ & $\begin{array}{l}0.023 \\
(2.40)^{* *}\end{array}$ & $\begin{array}{l}0.020 \\
(1.96)^{* *}\end{array}$ & $\begin{array}{r}0.014 \\
(1.38)\end{array}$ & $\begin{array}{l}-0.080 \\
(2.44)^{* *}\end{array}$ & 0.16 \\
\hline $\begin{array}{l}\text { Ratio of inward FDI } \\
\text { stock to GDP }\end{array}$ & $\begin{array}{l}-0.436 \\
(4.28)^{* * *}\end{array}$ & $\begin{array}{l}-0.422 \\
(4.12)^{* * *}\end{array}$ & $\begin{array}{l}-0.356 \\
(3.30)^{* * *}\end{array}$ & $\begin{array}{r}-0.179 \\
(1.63)\end{array}$ & $\begin{array}{l}1.354 \\
(3.79)^{* * *}\end{array}$ & $0.00^{* * *}$ \\
\hline $\begin{array}{l}\text { Share of ICT in total } \\
\text { capital stock }\end{array}$ & $\begin{array}{l}-0.436 \\
(2.50)^{* *}\end{array}$ & $\begin{array}{l}-0.510 \\
(2.90)^{* * *}\end{array}$ & $\begin{array}{l}-0.455 \\
(2.46)^{* *}\end{array}$ & $\begin{array}{c}-0.347 \\
(1.85)^{*}\end{array}$ & $\begin{array}{l}1.721 \\
(2.81)^{* * *}\end{array}$ & 0.08 \\
\hline $\begin{array}{l}\text { Credit to private sector } \\
\text { ( } \% \text { of GDP) }\end{array}$ & $\begin{array}{l}-0.424 \\
(3.80)^{* * *}\end{array}$ & $\begin{array}{l}-0.677 \\
(6.01)^{* * *}\end{array}$ & $\begin{array}{l}-0.723 \\
(6.10)^{* * *}\end{array}$ & $\begin{array}{l}-0.458 \\
(3.80)^{* * *}\end{array}$ & $\begin{array}{l}2.280 \\
(5.82)^{* * *}\end{array}$ & $0.00^{* * * *}$ \\
\hline $\begin{array}{l}\text { Population share with } \\
\text { at least secondary } \\
\text { education }\end{array}$ & $\begin{array}{r}-0.029 \\
(1.42)\end{array}$ & $\begin{array}{r}-0.022 \\
(1.08)\end{array}$ & $\begin{array}{r}-0.027 \\
(1.25)\end{array}$ & $\begin{array}{r}-0.006 \\
(0.29)\end{array}$ & $\begin{array}{c}0.086 \\
(1.23)\end{array}$ & 0.23 \\
\hline $\begin{array}{l}\text { Average years of } \\
\text { education }\end{array}$ & $\begin{array}{c}0.893 \\
(0.53)\end{array}$ & $\begin{array}{c}0.292 \\
(0.17)\end{array}$ & $\begin{array}{c}0.728 \\
(0.41)\end{array}$ & $\begin{array}{c}0.138 \\
(0.08)\end{array}$ & $\begin{array}{c}-2.095 \\
(0.36)\end{array}$ & 0.80 \\
\hline $\begin{array}{l}\text { Agriculture } \\
\text { employment share }\end{array}$ & $\begin{array}{r}-0.089 \\
(0.30)\end{array}$ & $\begin{array}{r}-0.399 \\
(1.32)\end{array}$ & $\begin{array}{l}-0.683 \\
(2.16)^{* *}\end{array}$ & $\begin{array}{r}-0.411 \\
(1.28)\end{array}$ & $\begin{array}{r}1.589 \\
(1.52)\end{array}$ & $0.04 * *$ \\
\hline $\begin{array}{l}\text { Industry employment } \\
\text { share }\end{array}$ & $\begin{array}{l}1.334 \\
(3.68)^{* * *}\end{array}$ & $\begin{array}{l}1.107 \\
(3.02)^{* * *}\end{array}$ & $\begin{array}{c}0.751 \\
(1.95)^{*}\end{array}$ & $\begin{array}{r}0.122 \\
(0.31)\end{array}$ & $\begin{array}{l}-3.292 \\
(2.59)^{* * *}\end{array}$ & $0.02 * *$ \\
\hline Observations & 276 & 276 & 276 & 276 & 276 & \\
\hline
\end{tabular}

Notes: The regressions were estimated jointly using the Seemingly Unrelated Regressions Estimator (SURE). Regressions include country fixed effects and time dummies. $t$-statistics are in parentheses. *denotes significance at the 10 percent level, ${ }^{* *}$ denotes significance at the 5 percent level, ***denotes significance at the 1 percent level. All explanatory variables are in natural logarithm, except the tariff measure, the capital account openness index, and the population share with at least a secondary education. FDI $=$ foreign direct investment; ICT =information and communications technology.

for all countries. We explore the possibility of heterogeneous effects of trade globalization, technological progress, and other variables across advanced and developing country groups (Table 5); results are, however, more tentative as the number of observations used for identification of group-specific effects is smaller. A differential effect was allowed for each variable of the Summary and Benchmark models (columns 1 and 2 of Table 5). While maintaining common time dummies, interaction terms between the regressors and a dummy for advanced economies were included to measure the difference between the effects for advanced economies and the estimated average effect for the full sample. In the last column of the table, we incorporate additional variables that are likely to have a different impact on advanced and developing economies including outward stock of FDI (related to outsourcing) and 
Table 3. Income Inequality Cross-Country and Panel Regressions: Robustness

\begin{tabular}{|c|c|c|c|c|c|}
\hline & (1) & (2) & (3) & (4) & (5) \\
\hline Model specification & $\begin{array}{l}\text { Long } \\
\text { regression } \\
\text { Summary } \\
\text { model }\end{array}$ & $\begin{array}{l}\text { Long } \\
\text { regression } \\
\text { Full model }\end{array}$ & $\begin{array}{c}\text { Long } \\
\text { regression } \\
\text { Benchmark } \\
\text { model }\end{array}$ & $\begin{array}{c}\text { Random } \\
\text { effects } \\
\text { Benchmark } \\
\text { model }\end{array}$ & $\begin{array}{c}\text { Between } \\
\text { effects } \\
\text { Benchmark } \\
\text { model }\end{array}$ \\
\hline \multicolumn{6}{|l|}{ Trade globalization } \\
\hline $\begin{array}{l}\text { Ratio of exports and } \\
\text { imports to GDP }\end{array}$ & $\begin{array}{c}-0.098 \\
(1.27)\end{array}$ & & & & \\
\hline Export-to-GDP ratio & & $\begin{array}{r}-0.017 \\
(0.24)\end{array}$ & $\begin{array}{r}-0.007 \\
(0.14)\end{array}$ & $\begin{array}{l}-0.067 \\
(2.60)^{* * *}\end{array}$ & $\begin{array}{l}-0.147 \\
(2.78)^{* * *}\end{array}$ \\
\hline Import-to-GDP ratio & & $\begin{array}{c}-0.070 \\
(1.06)\end{array}$ & & & \\
\hline 100 minus tariff rate & $\begin{array}{l}-0.003 \\
(2.03)^{* *}\end{array}$ & $\begin{array}{c}-0.004 \\
(1.79)\end{array}$ & $\begin{array}{r}-0.003 \\
(1.41)\end{array}$ & $\begin{array}{l}-0.003 \\
(3.26)^{* * *}\end{array}$ & $\begin{array}{c}0.005 \\
(0.93)\end{array}$ \\
\hline \multicolumn{6}{|l|}{ Financial globalization } \\
\hline $\begin{array}{l}\text { Ratio of cross-border } \\
\text { assets and liabilities } \\
\text { to GDP }\end{array}$ & $\begin{array}{r}0.045 \\
(1.08)\end{array}$ & & & & \\
\hline $\begin{array}{l}\text { Ratio of inward FDI } \\
\text { stock to GDP }\end{array}$ & & $\begin{array}{c}0.058 \\
(1.74)^{*}\end{array}$ & $\begin{array}{c}0.053 \\
(1.93)^{*}\end{array}$ & $\begin{array}{l}0.059 \\
(3.47)^{* * *}\end{array}$ & $\begin{array}{l}0.094 \\
(2.58) * *\end{array}$ \\
\hline $\begin{array}{l}\text { Ratio of inward } \\
\text { portfolio equity } \\
\text { stock to GDP }\end{array}$ & & $\begin{array}{r}0.001 \\
(0.59)\end{array}$ & & & \\
\hline $\begin{array}{l}\text { Ratio of inward debt } \\
\text { stock to GDP }\end{array}$ & & $\begin{array}{r}0.002 \\
(0.04)\end{array}$ & & & \\
\hline $\begin{array}{l}\text { Ratio of outward FDI } \\
\text { stock to GDP }\end{array}$ & & $\begin{array}{c}0.003 \\
(0.94)\end{array}$ & & & \\
\hline $\begin{array}{l}\text { Capital account } \\
\text { openness index }\end{array}$ & $\begin{array}{c}-0.020 \\
(1.72)^{*}\end{array}$ & $\begin{array}{l}-0.023 \\
(2.23)^{* *}\end{array}$ & & & \\
\hline \multicolumn{6}{|l|}{ Technology } \\
\hline $\begin{array}{l}\text { Share of ICT in total } \\
\text { capital stock }\end{array}$ & $\begin{array}{l}0.132 \\
(2.78)^{* * *}\end{array}$ & $\begin{array}{c}0.109 \\
(1.90)^{*}\end{array}$ & $\begin{array}{c}0.102 \\
(1.92)^{*}\end{array}$ & $\begin{array}{c}0.050 \\
(1.71)^{*}\end{array}$ & $\begin{array}{c}0.084 \\
(1.64)^{*}\end{array}$ \\
\hline \multicolumn{6}{|l|}{ Control variables } \\
\hline $\begin{array}{l}\text { Credit to private } \\
\text { sector }(\% \text { of GDP) }\end{array}$ & $\begin{array}{l}0.147 \\
(2.90)^{* * *}\end{array}$ & $\begin{array}{l}0.127 \\
(2.54)^{* *}\end{array}$ & $\begin{array}{l}0.103 \\
(2.41)^{* *}\end{array}$ & $\begin{array}{l}0.034 \\
(2.89)^{* * *}\end{array}$ & $\begin{array}{c}-0.010 \\
(0.22)\end{array}$ \\
\hline $\begin{array}{l}\text { Population share with } \\
\text { at least a secondary } \\
\text { education }\end{array}$ & $\begin{array}{r}0.006 \\
(1.68)\end{array}$ & $\begin{array}{c}0.006 \\
(1.54)\end{array}$ & $\begin{array}{r}0.005 \\
(1.37)\end{array}$ & $\begin{array}{c}-0.004 \\
(1.62)\end{array}$ & $\begin{array}{l}-0.014 \\
(3.62)^{* * *}\end{array}$ \\
\hline $\begin{array}{l}\text { Average years of } \\
\text { education }\end{array}$ & $\begin{array}{r}-0.285 \\
(1.11)\end{array}$ & $\begin{array}{c}-0.200 \\
(0.54)\end{array}$ & $\begin{array}{c}-0.263 \\
(0.79)\end{array}$ & $\begin{array}{c}-0.002 \\
(0.01)\end{array}$ & $\begin{array}{l}0.503 \\
(2.18)^{* *}\end{array}$ \\
\hline $\begin{array}{l}\text { Agriculture } \\
\text { employment share }\end{array}$ & $\begin{array}{c}0.010 \\
(0.22)\end{array}$ & $\begin{array}{r}-0.027 \\
(0.52)\end{array}$ & $\begin{array}{c}-0.026 \\
(0.49)\end{array}$ & $\begin{array}{c}0.014 \\
(0.61)\end{array}$ & $\begin{array}{c}0.010 \\
(0.32)\end{array}$ \\
\hline $\begin{array}{l}\text { Industry employment } \\
\text { share }\end{array}$ & $\begin{array}{c}-0.120 \\
(1.72)^{*}\end{array}$ & $\begin{array}{c}-0.177 \\
(1.84)^{*}\end{array}$ & $\begin{array}{c}-0.150 \\
(1.75)^{*}\end{array}$ & $\begin{array}{l}-0.119 \\
(2.56)^{* *}\end{array}$ & $\begin{array}{c}0.035 \\
(0.29)\end{array}$ \\
\hline $\begin{array}{l}\text { Initial level of GDP } \\
\text { per capita }\end{array}$ & & & & & $\begin{array}{c}-0.086 \\
(1.45)\end{array}$ \\
\hline
\end{tabular}


Table 3 (continued)

\begin{tabular}{lccccc}
\hline & $(1)$ & $(2)$ & $(3)$ & $(4)$ & $(5)$ \\
\cline { 2 - 6 } & $\begin{array}{c}\text { Long } \\
\text { regression }\end{array}$ & $\begin{array}{c}\text { Long } \\
\text { Summary } \\
\text { model }\end{array}$ & $\begin{array}{c}\text { Long } \\
\text { regression }\end{array}$ & $\begin{array}{c}\text { Random } \\
\text { effects }\end{array}$ & $\begin{array}{c}\text { Between } \\
\text { full model }\end{array}$ \\
$\begin{array}{c}\text { Menchmark } \\
\text { model }\end{array}$ & $\begin{array}{c}\text { Benchmark } \\
\text { model }\end{array}$ & $\begin{array}{c}\text { Benchmark } \\
\text { model }\end{array}$ \\
\hline $\begin{array}{l}\text { Dummy variable for } \\
\text { consumption-based } \\
\text { inequality }\end{array}$ & & & & & -0.072 \\
$\begin{array}{l}\text { Observations } \\
R \text {-squared }\end{array}$ & 51 & 51 & 51 & 292 & $(0.89)$ \\
\hline
\end{tabular}

Notes: The long regressions in columns 1-3 are cross-sectional regressions of the long-run change in the Gini on the long-run changes in explanatory variables. Observations are weighted by the number of years between the first and last observations for each country. The regressions in columns 4 and 5 are panel regressions, respectively with random and between effects, and include time dummies. Standard errors are clustered at the country level in columns 1-4. $t$-statistics are in parentheses. *denotes significance at the 10 percent level, ${ }^{* *}$ denotes significance at the 5 percent level, ***denotes significance at the 1 percent level. All explanatory variables are in natural logarithm, except the tariff measure, the capital account openness index, and the population share with at least a secondary education. FDI = foreign direct investment; ICT=information and communications technology.

the share of imports from developing countries (while controlling for the import-to-GDP ratio). There is some evidence that FDI assets increase inequality in advanced economies, while the share of imports from developing countries contribute to reduce it.

\section{Discussion}

The results of our empirical analysis add to the existing literature on the determinants of inequality by exploiting a newly compiled inequality data set for a broad number of developing and advanced economies. While it is wellknown that cross-country inequality data suffer from severe measurement issues, in this paper we made a serious attempt to compile the most reliable cross-country inequality data available. In doing so we ended up eliminating a large number of questionable observations thus significantly reducing our sample compared with those used in other studies in the existing literature. Despite the smaller number of observations, we believe that our sample has a larger signal-to-noise ratio due to significantly reduced measurement error.

While the globalization of trade has in the aggregate tended to reduce inequality, financial globalization, and FDI in particular, has tended to exacerbate the trend toward rising inequality. The results of the previous section's empirical analysis imply that the main factor driving the recent increase in inequality across a very broad range of countries has been 
Table 4. Income Inequality Panel Regressions: Robustness (Dependent Variable: Natural Logarithm of Gini)

\begin{tabular}{lccc}
\hline & $(1)$ & $(2)$ & $(3)$ \\
\cline { 2 - 4 } & $\begin{array}{c}\text { Benchmark } \\
\text { model }\end{array}$ & $\begin{array}{c}\text { Without } \\
\text { technology }\end{array}$ & $\begin{array}{c}\text { Without } \\
\text { globalization }\end{array}$ \\
\hline Model specification & -0.056 & -0.058 & \\
Export-to-GDP ratio & $(2.02)^{* *}$ & $(2.19)^{* *}$ & \\
& -0.003 & -0.002 & \\
100 minus tariff rate & $(3.17)^{* * *}$ & $(2.29)^{* *}$ & \\
Ratio of inward FDI stock to GDP & 0.042 & 0.049 & \\
& $(2.48)^{* *}$ & $(2.79)^{* * *}$ & \\
Share of ICT in total capital stock & 0.054 & & 0.055 \\
& $(1.95)^{*}$ & & $(2.00)^{*}$ \\
Credit to private sector (\% of GDP) & 0.054 & 0.053 & 0.067 \\
& $(4.08)^{* * *}$ & $(4.02)^{* * *}$ & $(4.56)^{* * *}$ \\
Population share with at least a secondary & 0.003 & 0.002 & 0.005 \\
education & $(1.17)$ & $(0.84)$ & $(1.82)^{*}$ \\
Average years of education & -0.175 & -0.035 & -0.392 \\
& $(0.93)$ & $(0.19)$ & $(1.88)^{*}$ \\
Agriculture employment share & 0.024 & 0.041 & -0.006 \\
& $(0.66)$ & $(1.21)$ & $(0.17)$ \\
Industry employment share & -0.112 & -0.109 & -0.149 \\
& $(3.02)^{* * *}$ & $(3.04)^{* * *}$ & $(4.14)^{* * *}$ \\
Observations & 292 & 292 & 292 \\
$R$-squared (within) & 0.39 & 0.37 & 0.33 \\
\hline
\end{tabular}

Notes: The regressions were estimated using panel regressions with country fixed effects and time dummies. Standard errors are clustered at the country level. $t$-statistics are in parentheses. *denotes significance at the 10 percent level, ${ }^{* *}$ denotes significance at the 5 percent level, $* * *$ denotes significance at the 1 percent level. All explanatory variables are in natural logarithm, except the tariff measure, the capital account openness index, and the population share with at least a secondary education. $\mathrm{FDI}=$ foreign direct investment; $\mathrm{ICT}=$ information and communications technology.

technological change. The top panel of Figure 7 shows that during our sample period 1981-2003 there was an annual increase in the Gini coefficient of 0.42 percent. ${ }^{16}$ A decomposition of the aggregate increase of the Gini shows that technology contributed 0.74 percent annual average increase with globalization contributing another 0.08 percent a year. The estimations suggest that increased access to education and a shift in employment away from agriculture had a mitigating effect on inequality. The small net adverse impact of globalization on inequality is a result of two offsetting forces. While the globalization of trade has in the aggregate tended to reduce

\footnotetext{
${ }^{16}$ The cited changes in the Gini are proportional changes. That is, suppose the absolute Gini (measured between 0 and 1) on average increases from $x(t)$ to $x(t+1)$ in a year. Then the annual increase in the Gini coefficient that we report is calculated as $\{[x(t+1) / x(t)-1] \times 100-100\}$ percent.
} 
Table 5. Income Inequality Panel Regressions: Robustness (Dependent Variable: Natural Logarithm of Gini)

\begin{tabular}{|c|c|c|c|}
\hline & (1) & (2) & (3) \\
\hline & $\begin{array}{l}\text { Summary } \\
\text { model }\end{array}$ & $\begin{array}{l}\text { Benchmark } \\
\text { model }\end{array}$ & $\begin{array}{c}\text { Benchmark } \\
\text { model with } \\
\text { additional } \\
\text { Variables }\end{array}$ \\
\hline \multicolumn{4}{|l|}{ Trade globalization } \\
\hline Ratio of exports and imports to GDP & $\begin{array}{c}-0.063 \\
(1.75)^{*}\end{array}$ & & \\
\hline Export-to-GDP ratio & & $\begin{array}{l}-0.060 \\
(2.05)^{* *}\end{array}$ & $\begin{array}{r}-0.048 \\
(1.42)\end{array}$ \\
\hline Import-to-GDP ratio & & & $\begin{array}{r}0.008 \\
(0.18)\end{array}$ \\
\hline Share of imports from developing countries & & & $\begin{array}{r}0.040 \\
(0.87)\end{array}$ \\
\hline 100 minus tariff rate & $\begin{array}{c}-0.002 \\
(1.78)^{*}\end{array}$ & $\begin{array}{l}-0.002 \\
(2.08)^{* *}\end{array}$ & $\begin{array}{c}-0.002 \\
(2.22)^{* *}\end{array}$ \\
\hline \multicolumn{4}{|l|}{ Financial globalization } \\
\hline Ratio of cross-border assets and liabilities to GDP & $\begin{array}{r}0.030 \\
(1.31)\end{array}$ & & \\
\hline Ratio of inward FDI stock to GDP & & $\begin{array}{l}0.042 \\
(2.01)^{* *}\end{array}$ & $\begin{array}{c}0.032 \\
(1.86)^{*}\end{array}$ \\
\hline Ratio of outward FDI stock to GDP & & & $\begin{array}{r}0.000 \\
(0.11)\end{array}$ \\
\hline Capital account openness index & $\begin{array}{r}-0.007 \\
(1.14)\end{array}$ & & \\
\hline \multicolumn{4}{|l|}{ Technology } \\
\hline Share of ICT in total capital stock & $\begin{array}{l}0.076 \\
(2.73)^{* * *}\end{array}$ & $\begin{array}{r}0.049 \\
(1.74)\end{array}$ & $\begin{array}{l}0.072 \\
(2.90)^{* * *}\end{array}$ \\
\hline \multicolumn{4}{|l|}{ Control variables } \\
\hline Credit to private sector ( $\%$ of GDP) & $\begin{array}{l}0.076 \\
(5.28)^{* * *}\end{array}$ & $\begin{array}{l}0.063 \\
(4.74)^{* * *}\end{array}$ & $\begin{array}{l}0.061 \\
(3.67)^{* * *}\end{array}$ \\
\hline $\begin{array}{l}\text { Population share with at least a secondary } \\
\text { education }\end{array}$ & $\begin{array}{r}0.003 \\
(0.78)\end{array}$ & $\begin{array}{r}0.001 \\
(0.39)\end{array}$ & $\begin{array}{r}0.000 \\
(0.17)\end{array}$ \\
\hline Average years of education & $\begin{array}{r}-0.063 \\
(0.31)\end{array}$ & $\begin{array}{r}-0.007 \\
(0.03)\end{array}$ & $\begin{array}{r}-0.005 \\
(0.03)\end{array}$ \\
\hline Agriculture employment share & $\begin{array}{c}0.044 \\
(1.19)\end{array}$ & $\begin{array}{c}0.056 \\
(1.28)\end{array}$ & $\begin{array}{r}0.054 \\
(1.35)\end{array}$ \\
\hline Industry employment share & $\begin{array}{l}-0.101 \\
(1.83)^{*}\end{array}$ & $\begin{array}{l}-0.115 \\
(2.25)^{* *}\end{array}$ & $\begin{array}{r}-0.093 \\
(1.53)\end{array}$ \\
\hline
\end{tabular}




\begin{tabular}{|c|c|c|c|}
\hline & (1) & (2) & (3) \\
\hline & $\begin{array}{l}\text { Summary } \\
\text { model }\end{array}$ & $\begin{array}{l}\text { Benchmark } \\
\text { model }\end{array}$ & $\begin{array}{c}\text { Benchmark } \\
\text { model with } \\
\text { additional } \\
\text { Variables }\end{array}$ \\
\hline \multicolumn{4}{|l|}{ Interaction terms with advanced economies dummy } \\
\hline Ratio of exports and imports to GDP & $\begin{array}{r}0.001 \\
(0.01)\end{array}$ & & \\
\hline Export-to-GDP ratio & & $\begin{array}{r}0.012 \\
(0.14)\end{array}$ & \\
\hline Import-to-GDP ratio & & & $\begin{array}{c}-0.119 \\
(1.36)\end{array}$ \\
\hline Share of imports from developing countries & & & $\begin{array}{c}-0.115 \\
(1.95)^{*}\end{array}$ \\
\hline 100 minus tariff rate & $\begin{array}{c}-0.001 \\
(0.14)\end{array}$ & $\begin{array}{r}0.001 \\
(0.14)\end{array}$ & \\
\hline \multicolumn{4}{|l|}{ Financial globalization } \\
\hline Ratio of cross-border assets and liabilities to GDP & $\begin{array}{r}-0.009 \\
(0.18)\end{array}$ & & \\
\hline Ratio of inward FDI stock to GDP & & $\begin{array}{r}-0.013 \\
(0.43)\end{array}$ & \\
\hline Ratio of outward FDI stock to GDP & & & $\begin{array}{c}0.061 \\
(1.87)^{*}\end{array}$ \\
\hline Capital account openness index & $\begin{array}{r}0.021 \\
(1.51)\end{array}$ & & \\
\hline \multicolumn{4}{|l|}{ Technology } \\
\hline Share of ICT in total capital stock & $\begin{array}{r}0.055 \\
(1.39)\end{array}$ & $\begin{array}{c}0.054 \\
(1.41)\end{array}$ & $\begin{array}{c}0.020 \\
(0.58)\end{array}$ \\
\hline \multicolumn{4}{|l|}{ Control variables } \\
\hline Credit to private sector ( $\%$ of GDP) & $\begin{array}{c}-0.056 \\
(1.16)\end{array}$ & $\begin{array}{r}-0.050 \\
(1.09)\end{array}$ & \\
\hline $\begin{array}{l}\text { Population share with at least a secondary } \\
\text { education }\end{array}$ & $\begin{array}{c}0.004 \\
(0.62)\end{array}$ & $\begin{array}{c}0.004 \\
(0.63)\end{array}$ & \\
\hline Average years of education & $\begin{array}{c}-0.966 \\
(1.43)\end{array}$ & $\begin{array}{c}-0.616 \\
(1.00)\end{array}$ & \\
\hline Agriculture employment share & $\begin{array}{r}-0.041 \\
(0.66)\end{array}$ & $\begin{array}{c}-0.050 \\
(0.81)\end{array}$ & \\
\hline Industry employment share & $\begin{array}{c}-0.073 \\
(0.38)\end{array}$ & $\begin{array}{c}0.046 \\
(0.24)\end{array}$ & \\
\hline Observations & 292 & 292 & 283 \\
\hline$R$-squared (within) & 0.39 & 0.41 & 0.43 \\
\hline
\end{tabular}

Notes: The regressions were estimated using panel regressions with country fixed effects and time dummies. Standard errors are clustered at the country level. $t$-statistics are in parentheses. *denotes significance at the 10 percent level, $* *$ denotes significance at the 5 percent level, $* * *$ denotes significance at the 1 percent level. All explanatory variables are in natural logarithm, except the tariff measure, the capital account openness index, and the population share with at least a secondary education. FDI = foreign direct investment; ICT = information and communications technology. 


\section{Figure 7. Decomposition of the Change in Income Inequality}

All Countries

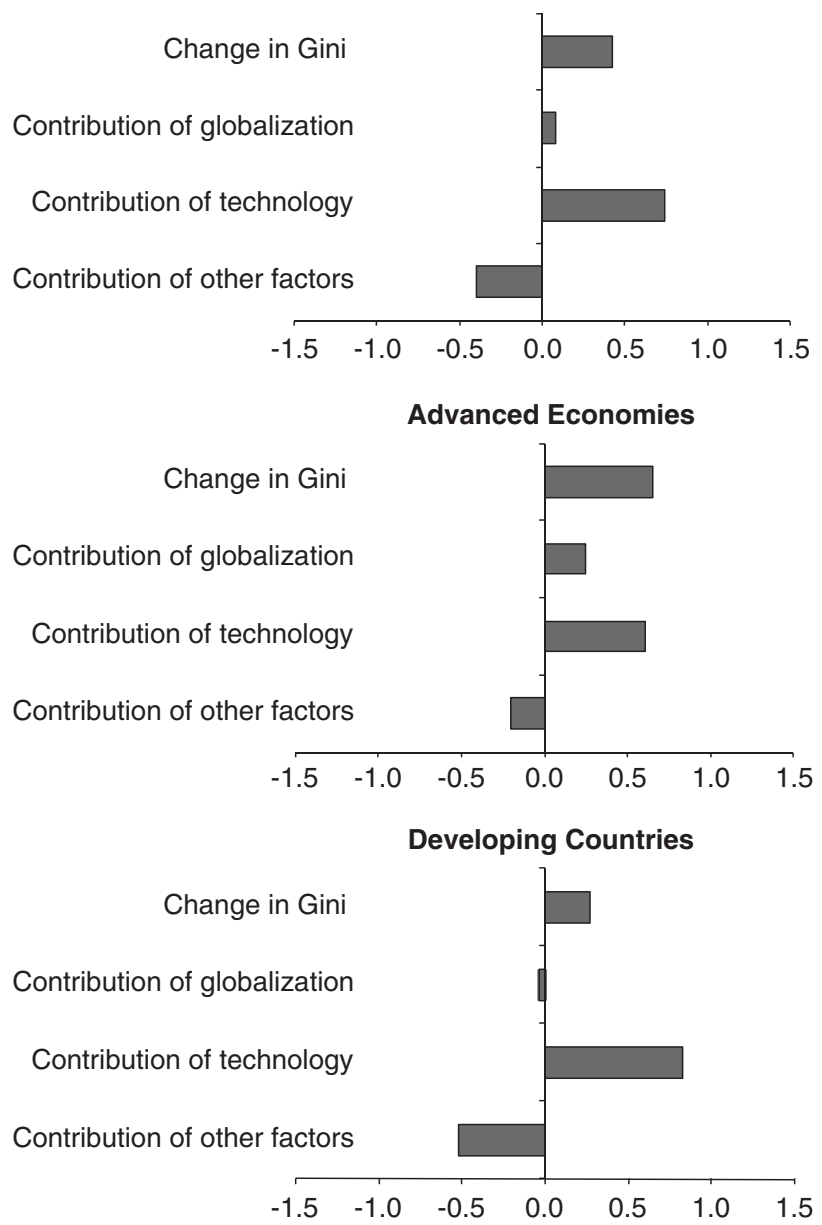

Notes: Income country groups are defined in the appendix. The contribution of each variable is computed as the annual change in the variable times the relevant regression coefficient on the variable.

inequality, financial globalization, and FDI in particular, has tended to exacerbate the trend toward rising inequality.

The decomposition done separately for developed (middle panel of Figure 7) and developing countries (bottom panel of Figure 7) suggests that the impact of globalization on inequality differs between these two groups of countries. ${ }^{17}$ Among developed countries, where the Gini coefficient has risen

\footnotetext{
${ }^{17}$ For comparability purposes to the overall sample (top panel of Figure 7), these results are based on a decomposition of the Benchmark model for both the advanced and developing
} 
by an average of 0.65 percent every year over the sample period, the adverse impact of globalization ( 0.25 percent), though still smaller than that of technological progress, is much larger compared with that in developing economies which is close to zero. Among developing countries, where the Gini coefficient has risen by about 0.27 percent a year on average, technology has been the main driving force of inequality with 0.83 percent increase of the Gini.

What explains the above patterns in inequality, as well as the marked differences between developed and developing countries? To answer this question, it is useful to look at the channels through which globalization and technology operate in terms of their impact on the distribution of income. The beneficial effects of trade on inequality in developing countries are particularly noticeable for agricultural exports, given agriculture still employs a large share of the workforce. Opening up of trade in agriculture increases the income of those who are dependent on agriculture for their livelihood in developing countries. Moreover, the shift of underemployed agricultural workers to manufacturing or service sectors where the marginal product of labor is higher also increases aggregate productivity, raising the income of those who continue to remain dependent on agriculture, and are typically among the lowest earning workers in developing countries.

For developed countries, imports from developing countries are associated with a reduction in inequality. This seems to contradict StolperSamuelson, and is consistent with lower paying low-end manufacturing jobs being substituted by higher paying service sectors in the expanding retail and consumer finance sectors. As might be expected, imports from other advanced economies do not have the same beneficial impact on inequality because higher-end imports are likely to affect higher paying domestic employment that may not be readily substituted by new service sector employment opportunities.

In both developed and developing countries, financial globalizationand FDI in particular - are associated with increases in income inequality. In both groups of countries, inward FDI is associated with rising inequality, while in developed countries outward FDI also has an additional negative impact. What explains this pattern? From the point of view of the host country, FDI tends to take place in higher skill and higher technology sectors. As a result, while FDI increases employment and income, this tends to favor those who already have relatively higher skills and education. As result, in both developing and developed countries, inward FDI increases the relative demand for higher skilled workers. Outward FDI in developed economies predictably tends to increase inequality by reducing employment opportunities in relatively lower skill sectors.

economies. Decomposition of alternative models incorporating additional regressors does not change the results qualitatively. 
The impact of technology on inequality is closely related to that of FDI. Technological progress, in both developed and developing countries, increases the premium on skills and tends to substitute away low-skill inputs (Birdsall, 2007). Technological progress thus increases the relative demand for higher skills, thereby exacerbating inequality in income. In developed countries, the use of technology is widespread in both manufacturing and services, affecting a substantial segment of the economy.

The adverse impact of financial deepening on inequality could suggest that while overall financial deepening is associated with higher growth, a disproportionately larger share of increased finance goes to those who already have higher incomes and assets which can serve as collateral.

In summary, the results of the analysis provide empirical support to the hypothesis that technological change played a major role in increasing inequality, while globalization played a smaller role. At the same time, our findings are at odds with arguments made by several economists (focusing primarily on country cases; summarized in Goldberg and Pavcnik, 2007) that the increase in international trade contributes to the rise in inequality.

\section{Conclusion}

Estimates using a new and more reliable data set on inequality and detailed measures of globalization provide some evidence that the observed rise in inequality across both developed and developing countries over the past two decades could be largely attributable to the impact of technological change. The contribution of increased globalization to inequality has in general been relatively minor. This reflects two offsetting effects of globalization: while increased trade tends to reduce income inequality, FDI tends to exacerbate it. Both financial globalization and technological progress tend to increase the relative demand for skills and education. While incomes have increased across all segments of the population in virtually all countries in the sample, incomes of those who already have higher levels of education and skills have risen disproportionately more.

Given that results are based on a short unbalanced panel data set and that estimation suffers from the usual endogeneity criticisms, it is important to note that our results are suggestive and should not be interpreted as definitive. The research presented in this paper could be extended along several dimensions. First, it is important to examine the impact that government policies, and fiscal policies in particular, have on the distribution of income. While one can conjecture that certain types of redistribution policies could ameliorate the adverse distribution of income, to date no comprehensive database of government policies across countries exists that would allow for an empirical examination. A second line of enquiry would be to examine the impact of FDI in different sectors, where the distributional consequences might be expected to vary. Finally, the impact of technological 
progress may vary by sector and type of technology. This too is, however, limited by the availability of comprehensive data across countries and over time, suggesting that extensions of this type would have to be limited to a single country or a relatively small group of countries.

\section{APPENDIX}

This appendix provides further details on the construction of the variables and the data sources used in the paper.

\section{A.I. Variable Definitions and Data Sources}

\section{Gini Index}

The primary source for the Gini index data is the World Bank Povcal database. For Mexico and Poland, the consumption-based Gini indices and quintile income shares were extrapolated historically for the period prior to 1992-for which only income-based measures are available - by assuming that the changes in consumption-based measures are identical to the observed changes in income-based measures that are available for that period. A similar process was applied to Peru's data prior to 1990, applying the changes in the observed consumption-based measures for earlier years to the income-based Gini index available from 1990 onward. For Argentina and Uruguay, the data cover only urban areas because of the high rate of urbanization in these two countries. For China and India, data with full country coverage (combining urban and rural data from the World Bank Povcal database) were provided by Shaohua Chen of the World Bank. When Povcal data were not available (mainly for advanced economies), the data from the Luxembourg Income Study were used, as provided in the World Income Inequality Database, Version 2.0b, May 2007 (WIDER).

These data are mostly available only until 2000. The following other sources were also used to increase coverage for advanced economies: data for Australia are from the Australian Bureau of Statistics; data for Germany are from the Deutsches Institüt für Wirtschaftsforschung; data for France are from the European Commission; household inequality data for Hong Kong SAR are from the Hong Kong Census and Statistics; household Gini index data for Japan are from Shirahase (2001); income share data for Japan measuring household consumption inequality and excluding agricultural households are from the Family Income and Expenditure Survey provided by the Japanese Statistics Bureau (all included in WIDER); and household inequality data for Korea were provided by Professor Kyungsoo Choi of the Korea Development Institute. The regressions used only actual (not interpolated) observations.

\section{Trade Globalization}

De facto trade openness is calculated as the sum of imports and exports of (non-oil) goods and services over GDP. The data are from the World Economic Outlook database (April 2007). Sectoral trade data on agriculture, manufacturing, and services are from the World Bank's World Development Indicators database (April 2007). De jure trade openness is calculated as 100 minus the tariff rate, which is an average of the effective tariff rate (tariff revenue/import value) and of the average unweighted tariff rate. The data are from a database prepared by IMF staff. Each component of the implied 100 minus tariff rate is interpolated linearly for countries with data gaps less than or equal to 
seven missing observations between 1980 and 2004. When data for either component (the effective tariff rate or the average unweighted tariff rate) are shorter than for the other, the shorter series is extrapolated using the growth rate of the longer series. Finally, for countries with only one of the two components, only the available one is used.

\section{Financial Globalization}

De facto financial openness is calculated as the sum of total cross-border assets and liabilities over GDP. Data on financial globalization are from the "External Wealth of Nations Mark II" constructed by Lane and Milesi-Ferretti (2007). The components of de facto financial openness in percent of GDP include (for both assets and liabilities) (1) FDI, (2) portfolio equity, (3) debt, (4) financial derivatives, and (5) total reserves minus gold (assets only). De jure financial openness refers to the capital account openness index (KAOPEN) from Chinn and Ito (2006). The index is based on principal components extracted from disaggregated capital and current account restriction measures in the IMF's Annual Report on Exchange Arrangements and Exchange Restrictions.

\section{Capital Stock and ICT Capital}

Fajnzylber and Lederman (1999) is the source of the capital stock series for the entire economy. This data set extends the capital stock series estimated by Nehru and Dhareshwar (1993) by adding the annual flow of gross fixed capital formation and assuming a 4 percent depreciation rate of the preexisting stock of capital. Fajnzylber and Lederman (1999) was further updated to recent years using the same methodology. ICT Capital is obtained from Jorgenson and Vu (2005) data series "Stock of ICT capital, in current U.S.\$." Jorgenson and Vu (2005) use series on IT investment from national expenditure data for computer hardware, software, and telecommunications equipment. The IT investment data is then incorporated into a perpetual inventory method applying varying depreciation rates to estimate the IT capital stock. This method assumes a geometric depreciation rate of 31.5 percent and a service life of seven years for computer hardware, 31.5 percent and five years for software, and 11 percent and 11 years for telecommunications equipment.

\section{Private Credit}

Each country's financial depth is estimated by its ratio of credit to the private sector by deposit money banks and other financial institutions to GDP. The source is the Financial Structure database prepared by Beck, Demirgüç-Kunt, and Levine (2000) and revised in March 2007. Data for China are based on IMF calculations.

\section{Education}

Data on educational attainment of the population ages 15 and older are from the Barro-Lee (2001) data set. The series used are the average schooling years in the population, and the share of the population with secondary and/or higher education.

\section{Employment}

Data on employment are from the World Bank's World Development Indicators database (April 2006). The shares in agriculture and industry are interpolated linearly for countries with data gaps of seven or fewer missing observations between 1980 and 
2005. For Bolivia, data are from the International Labor Organization's LABORSTA database for 1988-2001 and from the Instituto Nacional de Estadstica for 2002-05. For Ecuador, data for 1988-2005 are from the International Labor Organization's LABORSTA database. For Morocco, data for 1999-2002 are from the Direction de la Politique Economique Générale. For Paraguay, data for 1991-2005 are from the Departamento de Cuentas Nacionales y Mercado Interno, Gerencia de Estudios Económicos. For China, data for 1980-2004 are from the National Bureau of Statistics. For India, data for 1980-2004 are taken from the National Sample Survey Organization. For Taiwan Province of China, data for 1980-2005 are from the CEIC database.

\section{A.II. Income Country Groups}

\section{Countries used in estimation}

The sample of countries for which all variables used in the regressions were available consists of 51 countries, of which 20 are advanced economies and 31 are developing economies. Further disaggregation by income group using the World Bank classification uses the following income thresholds: low income, $\$ 875$ or less $(L)$; lower-middle income, $\$ 876-\$ 3,465(L M)$; upper-middle income, \$3,466-\$10,725 (UM); and high income, $\$ 10,726$ or more $(H) .\left(^{*}\right)$ indicates countries for which the Gini coefficient is constructed using consumption survey data.

\section{Advanced economies}

Australia $^{H}$, Austria $^{H}$, Belgium ${ }^{H}$, Canada $^{H}$, Denmark ${ }^{H}$, Finland ${ }^{H}$, France $^{H}$, Germany ${ }^{H}$, Ireland $^{H}$, Israel ${ }^{H}$, Italy ${ }^{H}, \operatorname{Japan}^{H}, \operatorname{Korea}^{H}$, Netherlands ${ }^{H}$, Norway ${ }^{H}$, Singapore ${ }^{H}$, Spain $^{H}$, Sweden ${ }^{H}$, United Kingdom ${ }^{H}$, and United States ${ }^{H}$.

\section{Developing economies}

Argentina $^{U M}$, Bangladesh ${ }^{* L}$, Bolivia ${ }^{L M}$, Brazil ${ }^{U M}$, Chile $^{U M}$, China $^{* L M}$, Costa Rica ${ }^{U M}$, Ecuador $^{L M}$, Egypt $^{* L M}$, El Salvador ${ }^{L M}{\text {, } \text { Ghana }^{* L}, \text { Guatemala }^{L M} \text {, Honduras }}^{L M}$, India $^{* L}$, Indonesia $^{* L M}$, Iran ${ }^{* L M}$, Kenya ${ }^{* L}$, Malaysia ${ }^{U M}$, Mexico*UM Pakistan $^{* L}$, Panama ${ }^{U M}$, Paraguay $^{L M}$, Peru ${ }^{L M}$, Philippines ${ }^{* L M}$, Sri Lanka* ${ }^{* L}$, Thailand ${ }^{* L M}$, Turkey ${ }^{* U M}$, Uganda $^{* L}$, Uruguay ${ }^{U M}$, Venezuela ${ }^{U M}$, and Zambia ${ }^{* L}$.

\section{REFERENCES}

Alesina, A., and R. Perotti, 1996, "Income Distribution, Political Instability, and Investment," European Economic Review, Vol. 40, No. 6, pp. 1203-28.

Alesina, A., and D. Rodrik, 1994, "Distributive Politics and Economic Growth," Quarterly Journal of Economics, Vol. 109, No. 2, pp. 465-90.

Angeles, L, 2010, “An Alternative Test of Kuznets' Hypothesis," Journal of Economic Inequality, Vol. 8, No. 4, pp. 463-73.

Atkinson, A.B., and F. Bourguignon, 2000, "Introduction: Income Distribution and Economics," in Handbook of Income Distribution, Vol. 1, ed. by A.B. Atkinson and F. Bourguignon (Amsterdam: Elsevier). 
Atkinson, A.B., and A. Brandolini, 2001, "Promises and Pitfalls in the Use of Secondary Data-Sets: Income Inequality in OECD Countries as a Case Study," Journal of Economic Literature, Vol. 39, No. 3, pp. 771-800.

Autor, D.H., L.F. Katz, and M.S. Kearney, 2008, "Trends in U.S. Wage Inequality: Revising the Revisionists," Review of Economics and Statistics, Vol. 90, No. 2, pp. 300-23.

Barro, R.J, 2000, "Inequality and Growth in a Panel of Countries," Journal of Economic Growth, Vol. 5, No. 1, pp. 5-32.

Barro, R.J., and J.-W. Lee, 2001, "International Data on Educational Attainment: Updates and Implications," Oxford Economic Papers, Vol. 53, No. 3, pp. 541-63.

Beck, T., A. Demirgüç-Kunt, and R. Levine, 2000, “A New Database on Financial Development and Structure," World Bank Economic Review, Vol. 14, No. 3, pp. 597-605. , 2007, "Finance, Inequality, and the Poor," Journal of Economic Growth, Vol. 12, No. 1, pp. 27-49.

Benabou, R, 1996, "Inequality and Growth," NBER Macroeconomics Annual, Vol. 11, pp. 11-74.

Berman, E., J. Bound, and Z. Griliches, 1994, "Changes in the Demand for Skilled Labor within U.S. Manufacturing: Evidence from the Annual Survey of Manufactures," Quarterly Journal of Economics, Vol. 109, No. 2, pp. 367-97.

Berman, E., J. Bound, and S. Machin, 1998, "Implications of Skill-Biased Technological Change: International Evidence," Quarterly Journal of Economics, Vol. 113, No. 4, pp. $1245-79$.

Birdsall, N, 2007, in Discussion of Impact of Globalization on the World's Poor, ed. by M. Nissanke and E. Thorbecke (Washington, DC: WIDER Book Lunch).

Bloom, N., M. Draca, and J. Van Reenen, 2011, "Trade Induced Technical change? The Impact of Chinese Imports on Innovation and Information Technology," NBER Working Paper No. 16717.

Bound, J., and A.B. Krueger, 1991, "The Extent of Measurement Error in Longitudinal Earnings Data: Do Two Wrongs Make a Right? Journal of Labor Economics, Vol. 9, No. 1, pp. 1-24.

Bourguignon, F., and C. Morrisson, 1998, "Inequality and Development: the Role of Dualism," Journal of Development Economics, Vol. 57, No. 2, pp. 233-57.

Borjas, G.J., R.B. Freeman, and L.F. Katz, 1997, "How Much Do Immigration and Trade Affect Labor Market Outcomes? Brookings Papers on Economic Activity, Vol. 1997, No. 1, pp. 1-67.

Brock, A., and S. Durlauf, 2001, "What Have We Learned from a Decade of Empirical Research on Growth? Growth Empirics and Reality," World Bank Economic Review, Vol. 15, No. 2, pp. 229-72.

Broda, C., and J. Romalis, 2008, "Inequality and Prices: Does China Benefit the Poor in America?," Working Paper (University of Chicago).

Chen, S., and M. Ravallion, 2004, "How Have the World's Poorest Fared since the Early 1980s?" World Bank Research Observer, Vol. 19, No. 2, pp. 141-69.

, 2007, "Absolute Poverty Measures for the Developing World, 1981-2004," World Bank, Policy Research Working Paper No. 4211.

Chinn, M., and H. Ito, 2006, "What Matters for Financial Development? Capital Controls, Institutions and Interactions," Journal of Development Economics, Vol. 81, No. 1, pp. 163-92. 
Claessens, S., and E.C. Perotti, 2007, "Finance and Inequality," Journal of Comparative Economics, Vol. 35, No. 4, pp. 748-73.

Cragg, M.I., and M. Epelbaum, 1996, "Why Has Wage Dispersion Grown in Mexico? Is it the Incidence of Reforms of the Growing Demand for Skills?" Journal of Development Economics, Vol. 51, No. 1, pp. 99-116.

Deaton, A, 2005, "Measuring Poverty in a Growing World (or Measuring Growth in a Poor World)," Review of Economics and Statistics, Vol. 87, pp. 1-19.

Deaton, A., and S. Zaidi, 2002, "Guidelines for Constructing Consumption Aggregates for Welfare Analysis," LSMS Working Paper No. 135 (Washington: World Bank).

Deininger, K., and L. Squire, 1996, "A New Dataset Measuring Income Inequality," The World Bank Economic Review, Vol. 10, No. 3, pp. 565-91.

Demirgüç-Kunt, A., and R. Levine, 2007, "Finance and Opportunity: Financial Systems and Intergenerational Persistence of Relative Incomes," Working Paper (Brown University).

Egger, H., and U. Kreickemeier, 2009, "Firm Heterogeneity and the Labor Market Effects of Trade Liberalization," International Economic Review, Vol. 50, No. 1, pp. 187-216.

Fajnzylber, P., and D. Lederman, 1999, "Economic Reforms and Total Factor Productivity Growth in Latin America and the Caribbean (1950-95)-An Empirical Note," Policy Research Working Paper No. 2114 (Washington: World Bank).

Feenstra, R.C., and G.H. Hanson, 1996, "Globalization, Outsourcing, and Wage Inequality," American Economic Review, Vol. 86, No. 2, pp. 240-5.

Fields, G.S, 2001, Distribution and Development (Cambridge: MIT).

Forbes, K, 2000, "A Reassessment of the Relationship between Inequality and Growth," American Economic Review, Vol. 90, No. 4, pp. 869-87.

Galor, O., and J. Zeira, 1993, "Income Distribution and Macroeconomics," Review of Economic Studies, Vol. 60, No. 1, pp. 35-52.

Galor, O., and O. Moav, 2004, "From Physical to Human Capital Accumulation: In-equality and the Process of Development," Review of Economic Studies, Vol. 71, No. 4, pp. 1001-26.

Goldberg, P.K., and N. Pavcnik, 2007, "Distributional Effects of Globalization in Developing Countries," Journal of Economic Literature, Vol. 45, No. 1, pp. 39-82.

Greenwood, J., and B. Jovanovic, 1990, "Financial Development, Growth and Income Distribution," Journal of Political Economy, Vol. 98, No. 5, pp. 1076-107.

Helpman, E., and A. Hoffmaister, 1997, "North-South R\&D Spillovers," The Economic Journal, Vol. 107, No. 440, pp. 134-49.

Jorgenson, D.W., and K. Vu, 2005, "Information Technology and the World Economy," Scandinavian Journal of Economics, Vol. 107, No. 4, pp. 631-50.

Kakwani, N.C, 1980, “On a Class of Poverty Measures," Econometrica, Vol. 48, No. 2, pp. 437-46.

Kose, A., E.S. Prasad, K. Rogoff, and S.-J. Wei, 2009, "Financial Globalization: A Reappraisal," IMF Staff Papers, Vol. 56, No. 1, pp. 8-62.

Kremer, M., and D. Chen, 2002, "Income Distribution Dynamics with Endogenous Fertility," Journal of Economic Growth, Vol. 7, No. 3, pp. 227-58.

Krugman, P, 2008, “Trade and Wages, Reconsidered," Brookings Papers on Economic Activity, Vol. 2008, Spring, pp. 103-54. 
Krusell, P., L.E. Ohanian, V. Rios-Rull, and G.L. Violante, 2000, "Capital-Skill Complementarity and Inequality: A Macroeconomic Analysis," Econometrica, Vol. 68, No. 5, pp. 1029-54.

Kuznets, S, 1955, "Economic Growth and Income Inequality," American Economic Review, Vol. 45, No. 1, pp. 1-28.

Lane, P.R., and G.M. Milesi-Ferretti, 2007, "The External Wealth of Nations Mark II: Revised and Extended Estimates of Foreign Assets and Liabilities, 1970-2004," Journal of International Economics, Vol. 73, No. 2, pp. 223-50.

Lawrence, R.Z., and M.J. Slaughter, 1993, "International Trade and American Wages in the 1980s: Giant Sucking Sound or Small Hiccup?," in Brookings Papers on Economic Activity, Microeconomics 2, ed. by Martin Neil Baily and Clifford Winston, pp. 161-226.

Machin, S., and J. Van Reenen, 2007, "Changes in Wage Inequality," Center for Economic Performance, Special Paper No. 18.

Nehru, V., and A. Dhareshwar, 1993, "A New Database on Physical Capital Stock: Sources, Methodology and Results (in English)," Revista de Analisis Economico, Vol. 8, No. 1, pp. 37-59.

Perotti, R, 1996, "Growth, Income Distribution, and Democracy: What the Data Say," Journal of Economic Growth, Vol. 1, No. 2, pp. 149-87.

Persson, T., and G. Tabellini, 1994, "Is Inequality Harmful for Growth? American Economic Review, Vol. 84, No. 3, pp. 600-21.

Piketty, T, 2003, "Income Inequality in France, 1900-1998," Journal of Political Economy, Vol. 111, No. 5, pp. 1004-42.

Piketty, T., and E. Saez, 2003, "Income Inequality in the United States, 1913-1998," Quarterly Journal of Economics, Vol. 118, No. 1, pp. 1-39.

Prasad, E.S., K. Rogoff, S.-J. Wei, and A. Kose, 2007, "Financial Globalization, Growth and Volatility in Developing Countries," in Globalization and Poverty, ed. by A. Harrison (Chicago: NBER), pp. 457-516.

Ravallion, M, 2004, "Competing Concepts of Inequality in the Globalization Debate," Brookings Trade Forum, Vol. 2004, No. 1, pp. 1-38.

_ 2006, "Looking Beyond Averages in the Trade and Poverty Debate," World Development, Vol. 34, No. 8, pp. 1374-92.

Ravallion, M., and S. Chen, 1996, "What Can New Survey Data Tell Us About Recent Changes in Distribution and Poverty?," World Bank Policy Research Working Paper No. 1694.

Robinson, S, 1976, "A Note on the U Hypothesis Relating Income Inequality and Economic Development," American Economic Review, Vol. 66, No. 3, pp. 437-40.

Roine, J., J. Vlachos, and D. Waldenström, 2008, "The Long-Run Determinants of Inequality: What Can We Learn from Top Income Data?, Working Paper (Stockholm School of Economics).

Roine, J., and D. Waldenström, 2008, "The Evolution of Top Incomes in an Egalitarian Society: Sweden 1903-2004," Journal of Public Economics, Vol. 92, No. 1, pp. 366-87.

Schindler, M, 2008, "Measuring Financial Integration: A New Dataset," IMF Staff Papers, Vol. 56, No. 1, pp. 222-38.

Sylwester, K, 2000, "Income Inequality, Education Expenditures, and Growth," Journal of Development Economics, Vol. 63, No. 2, pp. 379-98. 
Shirahase, S, 2001, "Japanese Income Inequality by Household Types in Comparative Perspective," Luxembourg Income Study Working Paper 268 (Syracuse, NY: Syracuse University), July, www.lisweb.ceps.lu/publications/liswps/268.pdf.

Stolper, W.F., and P.A. Samuelson, 1941, "Protection and Real Wages," Review of Economic Studies, Vol. 9, No. 1, pp. 58-73.

Temple, J, 2005, "Dual Economy Models: A Primer for Growth Economists," The Manchester School, Vol. 73, No. 4, pp. 435-78.

Verhoogen, E, 2008, "Trade, Quality Upgrading and Wage Inequality in the Mexican Manufacturing Sector," Quarterly Journal of Economics, Vol. 123, No. 2, pp. 489-530.

Winters, L.A., N. McCulloch, and A. McKay, 2004, "Trade Liberalization and Poverty: The Evidence So Far," Journal of Economic Literature, Vol. 42, No. 1, pp. 72-115.

World Income Inequality Database, 2005, "United Nations University-World Institute for Development Economic Research (WIDER).

World Bank, World Development Report, 2006: Equity and Development.

World Bank, Global Economic Prospects, 2008: Technology Diffusion in the Developing World.

Yeaple, S.R, 2005, "A Simple Model of Firm Heterogeneity, International Trade, and Wages," Journal of International Economics, Vol. 65, No. 1, pp. 1-20. 